University of Louisville

ThinkIR: The University of Louisville's Institutional Repository

$12-2012$

\title{
"Lessons and exercises in polite literature" : the pedagogy and literature curriculum of Mother Columba Carroll, a Sister of Charity of Nazareth.
}

Anna M. Powell

University of Louisville

Follow this and additional works at: https://ir.library.louisville.edu/etd

\section{Recommended Citation}

Powell, Anna M., "'Lessons and exercises in polite literature" : the pedagogy and literature curriculum of Mother Columba Carroll, a Sister of Charity of Nazareth." (2012). Electronic Theses and Dissertations. Paper 1148.

https://doi.org/10.18297/etd/1148

This Master's Thesis is brought to you for free and open access by ThinkIR: The University of Louisville's Institutional Repository. It has been accepted for inclusion in Electronic Theses and Dissertations by an authorized administrator of ThinkIR: The University of Louisville's Institutional Repository. This title appears here courtesy of the author, who has retained all other copyrights. For more information, please contact thinkir@louisville.edu. 


\title{
"LESSONS AND EXERCISES IN POLITE LITERATURE": THE PEDAGOGY AND LITERATURE CURRICULUM OF MOTHER COLUMBA CARROLL, A SISTER OF CHARITY OF NAZARETH
}

\section{By}

\author{
Anna M. Powell \\ B.A., Southeast Missouri State University, 2009

\begin{abstract}
A Thesis
Submitted to the Faculty of the

College of Arts and Sciences of the University of Louisville

in Partial Fulfillment of the Requirements

for the Degree of
\end{abstract}

Master of Arts

Department of English

University of Louisville

Louisville, Kentucky

December 2012 
Copyright 2012 by Anna M. Powell

All rights reserved 
"Lessons and Exercises in Polite Literature": The Pedagogy and Literature Curriculum of Mother Columba Carroll, a Sister of Charity of Nazareth

\section{By}

Anna M. Powell

B.A., Southeast Missouri State University, 2009

A Thesis Approved on

November 14, 2012

by the following Thesis Committee:

Carol Mattingly, Thesis Director

Susan Griffin

Nancy M. Theriot 


\section{DEDICATION}

This thesis is dedicated to my grandparents, Denman and Alice Powell, who inspired me to follow in their legacy of education, and my parents, Mark and Kim Powell, for their unconditional love and support.

It is also dedicated to the Sisters of Charity of Nazareth in honor of their 200 years of service in empowering women through education, and to Mother Columba Carroll, SCN, whose intelligence and passion for literature and teaching is a source of inspiration. 


\section{ACKNOWLEDGEMENTS}

No project of this magnitude can be completed without the assistance of many wonderful, dedicated individuals. I want to especially thank my thesis chair, Dr. Carol Mattingly, for the incalculable amount of time she dedicated to my thesis. It is hard to imagine completing this project without her encouragement, mentorship, council, and friendship. I also want to thank my thesis committee members, Dr. Susan M. Griffin and Dr. Nancy M. Theriot, for their time, patience, and guidance through the writing process.

My love and gratitude also goes to the Sisters of Charity of Nazareth for their support. Special recognition is deserved by the SCN Archives, which house the wonderful collections that are the basis of my research; the SCN Archives Director, Kathy HertelBaker, for her assistance and allowing me freedom to pursue this project; and Elaine McCarron, SCN and Rachel Willett, SCN, for their support and encouragement. A special acknowledgment must also go to Patricia Kelley, SCN, whose love and presence is missed daily. It has been a true blessing to work with the SCN Community, and grow in my understanding of what it means to be a woman of perseverance, dedication, love, and faith.

My deepest appreciation also goes to the many friends and family members who offered a listening ear and words of encouragement. Thanks to my parents, Mark and Kim Powell, and to my siblings, Sarah Wilson and Grace Powell, for their patience and encouragement; to my dear friends Brett Hammond, Jordan Rumsey, Sandra Grunzinger, and Caleb Tankersley for their listening ear; and finally, the teachers and professors whose faith in me gave me the courage to continue my education. 


\begin{abstract}
"LESSONS AND EXERCISES IN POLITE LITERATURE":

THE PEDAGOGY AND LITERATURE CIRRICULUM OF

MOTHER COLUMBA CARROLL, A SISTER OF CHARITY OF NAZARETH
\end{abstract}

Anna M. Powell

November 14, 2012

This study will examine Nazareth Academy, a prestigious private female academy, and Mother Columba Carroll's, SCN pedagogy and literature curriculum. The first half of the study will create a snapshot of the Academy from 1855 to 1870 , examining the significance of the school, and providing a general understanding of its students. It will then examine Mother Columba Carroll, her life and the external influences that could have shaped her curriculum. The second half will analyze her literature curriculum, examining the wide range of literary genres included, and especially exploring the influence of fiction within the curriculum. Fiction was long debated among Carroll's contemporaries as being dangerous for the young female mind. Carroll's literature curriculum provides proof of the inclusion of fiction, not only in the school library, but as part of the curriculum. It will also exam the trends within the literature that Carroll chose to include in her curriculum. 


\section{TABLE OF CONTENTS}

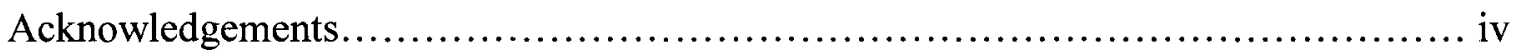

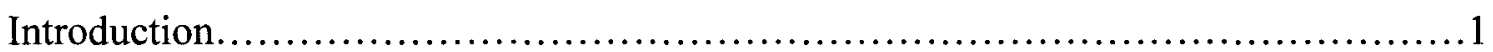

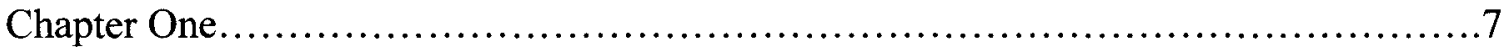

Role of Women Religious..................................................

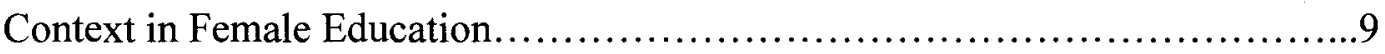

The Sisters of Charity of Nazareth Educational Ministry .......................13

Mother Columba Carroll.......................................................... 20

Carroll's Pedagogical Philosophy......................................... 24

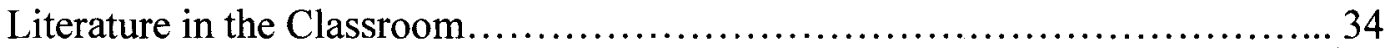

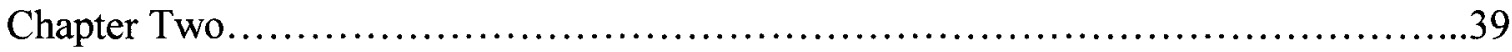

Popular Fiction.......................................................... 42

Popular Literature and Female Writers...................................... 45

Classics...................................................................... 50

Political Writers........................................................... 52

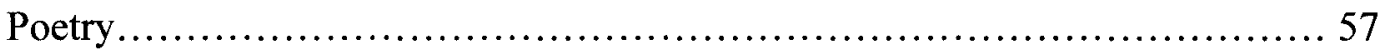

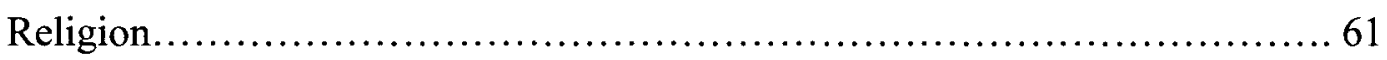

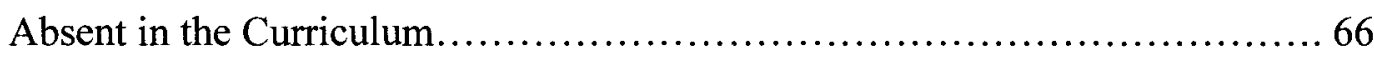

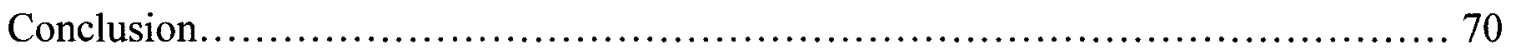

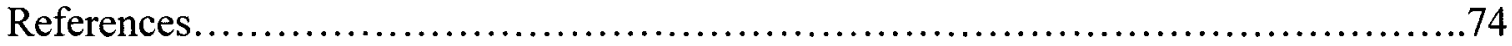

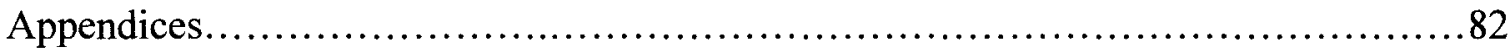

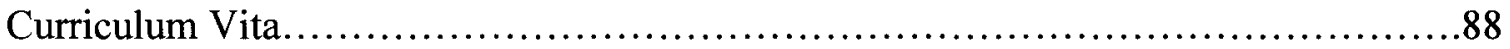




\section{INTRODUCTION}

In the increasing investigation of the foundation of female education in the United States, a gap has formed between our investigation of the eastern Protestant academies and the southern Catholic academies. Kentucky offers a sound place to begin researching Catholic-influenced female academies. It was a settling ground for a second wave of Catholic settlers from Maryland, and its background in education is extensive, with schools for the education of young men being established as early as the 1770s (Lewis). The question, then, became who was responsible for the education of the girls? Among the first responders to this disjunction in education were the fledgling Catholic women religious communities who were organizing themselves in response to the needs of the time, such as the Sisters of Charity of Nazareth (SCN). Beginning shortly after their 1812 foundation, the SCNs began establishing a series of pay/boarding female academies and free schools.

A thorough investigation of Catholicism's influence on female education, or even the influence of the SCNs, would require years of research. A case study of the views of one SCN educator, Mother Columba Carroll, ${ }^{1}$ and her writings provide some insight into the world of the Catholic academy. The age of this Order, combined with its long involvement in female education and the rapid proliferation of its institutions, makes it an excellent candidate for examination. Additionally, the SCNs' archives provide a wealth of information relating to the operations of their academies. The main focus of this thesis

\footnotetext{
${ }^{1}$ See Image 3 and 4.
} 
will be Nazareth Academy, the SCN flagship academy, which began as a one-room schoolhouse, but within a decade was an imposing boarding school with accommodations for over a hundred students. Nazareth Academy would continue to grow and expand through the 1870 s. $^{2}$ More specifically, this study critically examines the literary education in the institution, focusing on the views and educational method of Mother Columba Carroll, while placing the curriculum within the educational context of the era. The impact of Carroll's curriculum would be far-reaching, even beyond her role in the classroom. Carroll's pupils would go on to become teachers and mothers, both roles that would place them in positions of educational authority. Additionally, Carroll's role as the head of Nazareth Academy made her head of the young Sister-teachers' education, ensuring that her beliefs about education would also influence the teachers coming out of the SCN community. Many of young Sister-teachers would teach in the thirteen additional academies in Kentucky and Mississippi opened between 1814 and the 1870s.

The first chapter will examine the context in which Carroll's curriculum was created. An understanding of Nazareth Academy, its history and significance allows for a better understanding of the role of the institution. While education does not take place in a vacuum, the female academy did stand as an entity away from the world. Academy students lived away from their homes and loved ones, many for the first or only time, engaging in a journey of education with others in a similar position. Thus, a study of the space claimed by these young women and their teachers is necessary, as it is difficult to gain an understanding of the world in which these women lived without exploring this female space. The first chapter will also examine external factors, such as the antiCatholic sentiment that plagued the era, and trends in female education, in order to give a

\footnotetext{
${ }^{2}$ See Image 1 and 2.
} 
more conceptual understanding of the era. Finally, it will examine the life of Mother Columba Carroll who was the Directress of Study from 1832-1862 and 1868-1874. A highly influential educator within the academy, she was also the creator of the literature curriculum used in the school.

The second chapter examines the literature curriculum, and focuseslocated within the curriculum, examining the significance of Carroll's literary choices and its influence upon her students. The purpose of this examination is two-fold. Primarily, Mother Columba Carroll's curriculum provides evidence of the types of literature and the particular texts that were incorporated into a prestigious southern female academy in the ante-bellum through post Civil War years. There has been a concerted effort in reexamining female academies and institutions, recovering their historical significance while pushing beyond the notion that these institutions were merely finishing schools that taught proper behavior but had little academic merit. This project seeks to add to the understanding of the literature available to the students at Nazareth Academy, which adds to an understanding of female education.

Secondly, it also serves to work towards reclaiming the literary texts used in the academy and their role in literary history. The influence of classics, religion, poetry, and politics is explored in relationship to the norms in female education, as is the role of women authors, popular fiction, domestic, and sentimental texts. For many of the texts explored in this thesis, there has been and continues to be scholarship evaluating their influence on readers, and by extension their significance in literary history. Much of the focus on women's reading habits in recovery has focused on readership in private sector/life or in literary societies. Carroll's text serves to illuminate that, within Nazareth 
academy, works such as those by Lydia Sigourney, Jane Austen, and Maria Edgeworth, were not only for private consumption, but were to be taught in the classroom. This provides a fuller understanding of how these texts were being utilized by female readers.

Central to understanding this argument is the metaphor of separate spheres and its influence in our understanding of mid-nineteenth-century female academy education. Contemporary scholarship continues to complicate the centrality of the separate spheres metaphor, ${ }^{3}$ as the metaphor is problematic because it places limitations on the influence of women and can oversimplify gender relationships. However, the metaphor also has a strong basis in history. While I acknowledge that our understanding of the separatespheres metaphor has become increasingly complicated, the metaphor offers a framework in which to enter the academic conversation and serves to inform much of my reading in female education.

The metaphor of separate spheres has moved beyond Tocqueville's historical observations on the separation between the sexes, which were reinforced in the 1960 s by Barbara Welter and Aileen S. Kraditor. ${ }^{4}$ Their scholarship was a way to address the social and cultural history of women, whereas previous scholarship had portrayed women's history as limited to the political march towards suffrage. Seeking to better understand the influence and force that women played, Welter's and Kraditor's use of the separate-

\footnotetext{
${ }^{3}$ The metaphor is problematic in many ways, one of which is it is used "often interchangeably, [to refer] to an ideology imposed on women, a culture created by women, a set of boundaries expected to be observed by women. Moreover, the metaphor helped historians avoid thinking about race; virtually all discussion of the subject until very recently has focused on the experience of white women, mostly of the middle class" (Kerber 17).

${ }^{4}$ Welter's work focused on women's fiction and literature and identified the stereotype that she called the "Cult of True Womanhood," and did much work in identifying the key virtues of femininity as domesticity, piety, purity, and submission. Kraditor's text, Up from the Pedestal, was a historiographical analysis of period documents, in which she claims that the existence and question of the female sphere is central to understanding American feminism. Gerda Lerner is often identified as one of the key scholars working on separate spheres; however, her work focused on class differences that were not relevant to the purpose of this study.
} 
sphere metaphor was a strategy to study women analytical in social history (Kerber 37). The scholarship of spheres was dramatically shifted in 1975 because of Carroll SmithRosenberg's groundbreaking article "The Female World of Love and Ritual." In this work, Smith-Rosenberg argues that there was a distinctive female culture, where women were tied together by emotional and sometimes erotic bonds, and engaged with each other during key life stages such as childbirth and the rearing of children. This distinctive female culture would be explored more in depth by such scholars as Blanche Weisen Cook, Kathryn Kish Sklar, and Nancy F. Cott, who were engaged in examining the nature of female friendship, the role of the domestic, and the complexity of motherhood. ${ }^{5}$ Their work sought to identify complexities and introduce a female culture (Kerber 16). This avenue of study was extended by Carl N. Degler, ${ }^{6}$ who used the metaphor to explore advantages and disadvantages of the domestic and to argue that women used their sphere to assert control in the domestic sphere.

Likewise, this study is also building on the foundation laid by scholars such as Mary Beth Norton, Mary Kelley, Nina Baym, Kim Tolley, Bruce Leslie, Nancy Beadie, Barbara Sicherman, and many others, whose efforts have contributed to our understanding of the role of women, female education and readership, as well as women writers. These, and other scholars like them, have set an academic framework for exploring the tensions between the expectations of the domestic and the desire for more within nineteenth-century women's writing. Carroll's text adds to this conversation; it is

\footnotetext{
${ }^{5}$ Cook focused on the powerful and influential female friendships of women with significant political careers in the late nineteenth century. Kish Sklar's biography of Catharine Beecher examines Beecher's emphasis on domesticity, nurture, and education. Cott examined the practice of separate spheres in middleclass women's diaries and letters, and that domesticity was seen by women as being in opposition to the women's movement.

${ }^{6}$ Carl N. Degler, At Odds: Women and the Family in America from the Revolution to the Present.
} 
a study in contradictions, with her personal writings, her text on pedagogy, as well as her choices and development in her literature curriculum revealing a woman with high intellectual expectations of her students, as well as a woman who questions the veracity of the "cult of motherhood." Yet, Carroll is also a woman of her generation, fulfilling the role of an educator and moral influence, and living within the cultural limitations of the nineteenth century. While this study in contradictions cannot be resolved absolutely, it is the study of these tensions that will be explored in the following chapters. 


\section{CHAPTER 1}

\section{The Role of Women Religious}

As the academic investigation into the history of female academies and education continues, the prevalence of the Protestant literacy myth ${ }^{7}$ remains strong. June Edwards's introduction to her 2002 text on key American female educators notes that "a common element among these women [key female educators] was the role that religious faith played in their educational beliefs and practices. Although raised in various Protestant churches, most took from their particular denomination what spoke to their souls and affirmed them as creative, talented leaders" (xvi). Edwards's text is an excellent, concise history on key female educators in American history, but her work illustrates a clear emphasis on the influence of Protestantism on education, while overlooking the roles and influence of other religious groups.

Similarly, Christie Anne Farnham's text, The Education of the Southern Belle, 1994, briefly acknowledges the role of Catholic schools, noting that the Ursuline academy in New Orleans is possibly the first female academy in the United States, and that by " 1808 there were two additional well-known Catholic schools, Nazareth and

\footnotetext{
${ }^{7}$ The term "Protestant literacy myth" is used by Carol Mattingly to describe the commonly held belief that Protestant religious groups are responsible for the strong education system in the United States. This belief is centered on the argument that the Puritans' belief that all believers should be able to read the Bible, when transplanted in America, became the foundation for many institutions of learning. While the Puritans and other Protestant groups are responsible for a large number of educational institutions, this mindset ignores the contributions of other religious groups, such as Catholic institutions.
} 
Loretto, in Kentucky", (36); however, there is no further examination of how these schools compare to other similar institutions, and the majority of the plethora of examples in the text focus on Protestant institutions. While the purpose of this thesis is not to deny or even minimize the influence that Protestantism had on female education in America, its intention is to add to our understanding of the diversity of influences in female education, and to highlight those made by Catholicism and American women religious. While some scholars, such as Carol Mattingly, have added to our understanding of the work of American Catholic Sisters, overall their influence has been neglected in the academic conversation regarding female education. The reasons for this discrepancy are often obvious; the archives for the early Catholic academies are often held by individual Orders and can be difficult to access, and there is a lack of published education texts written by Catholic Sisters. ${ }^{9}$ While key educators, such as Catharine Beecher and Sara Josepha Hale, used publishing as the means of their livelihood, as well as a way to fund new projects and keep old projects running, the writings done by Sisters were limited to the walls of the convent.

Publishing in the nineteenth century presented unique barriers for the Catholic Sister. Her unmarried status meant she would need a male to act as her legal advocate and voice within the courts or the publishing house, but her role as a Sister removed her from the authority of her father, thus limiting her options unless a priest could act in that capacity. Moreover, books written by Sisters had to be approved not only by the leaders

\footnotetext{
${ }^{8}$ Farnham's footnote indicates that she is citing Woody's Women's Education vol.1, 329. This source, however, is incorrect, as both the Sisters of Loretto and the Sisters of Charity of Nazareth were founded in 1812 , and did not found their schools until after that date. Both orders did run highly respected academies. ${ }^{9}$ The title of Sister is different from that of a Nun. While both are women religious, Sisters are engaged in ministries outside of their convent, while Nuns are cloistered, meaning they live within the walls of their convent and rarely engage in outside ministry.
} 
of their order, but also had to be approved by the hierarchy of the Catholic Church and published through approved publishers. But there were additional complications besides difficulty in publishing, in the form of the expectations of women religious. Part of a woman religious' charism ${ }^{10}$ was to live a life of humility, keeping out of public attention, which allowed a Sister's work to bring a greater glory to God and not to an individual or her Order. However, just because works by Catholic Sisters regarding their views on education are difficult to find, one should not assume that they do not exist or that they do not offer a valuable glimpse into a relatively unexplored environment of female education in the nineteenth century.

\section{Context in Female Education}

The female boarding school represents a unique part of nineteenth-century female development. The academy movement is seen by Christie Anne Farnham as a second stage in the slow development of female education, coming after the rise of the French/ Latin schools movement, and forming the first form of higher female education (37 - 43). In the ante-bellum period, female higher education is seen as equivalent with the female academy or seminary (Wayne 73). Though the term "academy" was not a standardized term and encompassed many institutions from small, poorly run institutions run by one or two teachers, to large institutions that would later form some of the most influential female colleges in the nation, the academy movement was an important part in the development of female education. ${ }^{11}$

\footnotetext{
${ }^{10}$ Religious Orders use the word charism to describe their spiritual orientation and any special characteristics of their mission or values that might be exhibited as a result of the vows that they have taken.

${ }^{11}$ Nancy Beadie, in her article "Female Students and Denomination," summarizes the difficulty faced by scholars when writing on academies as "the great heterogeneity that existed among them. Academies varied with respect to the age and sex of their students; the level and content of their curricula; their size; their ownership; their relationships to church, state, or township (or lack thereof); their social geography; and
} 
The academy movement, it has been argued, was the result of the cult of true womanhood and republican motherhood, both of which elevated the status of women in the home. It was argued that women needed a better education in able to be better influences on their children and raise educated American sons and daughters. This idea was often encouraged by advocates of female education in order to justify the need for more education for females. The academy movement became tied with the writings of key female educators, who not only wrote on education, but also put their ideas into practice in their own institutions. For example, Emma Willard's legacy includes writing a famous appeal to the New York legislature for public funds for female schools, but she also opened Middlebury Female Seminary in 1814 and later Troy Seminary in 1821. Catharine Beecher, one of the most influential writers of female education, opened Hartford Female Seminary in 1823, and would later organize the American Women's Education Association (Edwards 8; Kleinberg 63-64). Mary Lyon, who was also a graduate of Troy Seminary, established Mount Holyoke in 1837. Thus, some of the most influential voices in female education and in advocating for female teachers were also the same voices advocating for and founding female academies, adding to the influence of the academy movement (Preston 536-37).

In addition to being an influential movement, the academy movement also rapidly disseminated. The period between 1790 and 1830 saw the founding of 182 academies and 14 female seminaries. The period between 1830 and 1860 saw the opening of an estimated addition of at least 158 more female schools. This movement was in response to the growing call for educational opportunities for young women, as well as for more

their relative wealth or poverty. Moreover, academies changed over time. It is thus difficult to generalize about academies" (76). 
opportunities for the social and interpersonal development of young women of a certain economic standing. These female academies had approximately the same enrollment as their male counterparts (Kelley Learning to Stand 67, 83). Nancy Beadie's research reveals that:

From the late eighteenth to the late nineteenth centuries, academies were the dominant form of schooling beyond the primary level in the United States. Until the 1880 s, the number of academies and academy students outnumbered high schools and high school students. At mid- century the proportion of 10 to 19-year olds that attended academies was approximately 13-21 percent, a figure that compares favorably with rates of high school attendance as late as 1890 . ("Female Students and Denomination" 75)

Despite the explosion in the number of female academies, there was no guarantee that a school would be successful. Nancy Beadie reports that while "female academies earned larger total revenues than male academies. In 1838,1845 , and 1850 , female academies earned the largest total revenues of any academies in the system" ("Female Students and Denomination" 81); however, an equal number of schools struggled financially.

Financial stability is one area where women religious had an advantage over the proprietor schools operated by scholar-educators such as Catharine Beecher's Hartford Academy or Mary Lyon's Mount Holyoke Academy. ${ }^{12}$ Whereas Protestant-run schools often had to pay up to eighty percent of their income in salaries to teachers (who remained underpaid), academies run by Sisters only had to care for their Sisters and could

\footnotetext{
${ }^{12}$ The following paragraphs contrast the academies of women religious with those run by Protestant individuals. The contrasts are based off of academic research and archival research on women religious. However, the arguments are also educated generalizations, and as such, there could be academies run by Orders of women religious who do not fit perfectly within this model.
} 
put the additional funds into improving their institution or send them back to the Order (Beadie "Female Students and Denomination" 82). These groups of women religious had the advantages of being able to accept young women into their ranks who would then undertake a vow of poverty, living together in communal living and offering support for one another. This allowed for these orders to found and run not only their original, flagship academy but also build additional schools (Mattingly 163-64). Additionally, if an academy did struggle, the Sisters had the option of closing it and simply reassigning its Sisters to a different academy. It was unlikely that closing an academy would lead to financial devastation, which was not the case for the independent proprietor institutions. Another area where women religious had an advantage over their Protestant counterparts was in the area of teachers. The need for more teachers and to provide for teacher education in the United States was acknowledged, especially after Emma Hart Willard published her 1819 speech calling for the establishment of teacher training programs (Farnham 61; Wayne 77). Advocates for female education, such as Catharine Beecher, opened schools for the training of teachers in order to help supply the large demand, but also to raise the standard of education among teachers, which would, in turn, raise the standard of education for the students. However, Beecher still faced the problem that as soon as her teachers married, they would likely quit working unless faced with financial problems, in which case the wife might return to teaching in her home to bring in additional income. However, for the majority of female teachers, marriage brought with it an implied end of public teaching.

After the loss of teachers or in the face of growth, Protestant academies were forced to look for new teachers, and hope that they had a satisfactory education. In 
contrast, if an academy run by women religious needed a new teacher, the leadership of an Order reserved the right to reassign teachers from one school to another. This meant that it was rare for women religious to have to search outside their Order for a new teacher. In order to produce a sufficient number of teachers to run all of an Order's schools and academies, the leadership of an Order worked to ensure their members had an education, and then provided additional teacher preparation for those who were entering the field of education. To handle this, each young sister after entering the community would spend several years in preparation for the classroom, as well as adapting herself to the experiences of her new life as a woman religious. This gave religious Orders a mobile workforce who had received and undergone a standardized teacher-education regimen, and, moreover, were highly unlikely to leave their work in order to marry. This greatly added to the individual academy, since it was assured to be well-staffed and that questions of general concern, such as operations and curriculum, were already decided (Greenwell 79-80).

\section{The Sisters of Charity of Nazareth Educational Ministry}

The Sisters of Charity of Nazareth (SCNs) are a community of Catholic Sisters, founded in 1812 outside of Bardstown, Kentucky. One of the principal reasons for their foundation was the education of young women living on the Kentucky frontier. After the establishment of their first school, Nazareth Academy, in 1814, the Order quickly gained a reputation for providing excellent female education (McGann Mother Columba 1 -2). Between the opening of that first academy and the end of Carroll's life in the 1870s, the SCNs opened thirteen additional academies in Kentucky and Mississippi (see Table 1). 
Nazareth Academy was the flagship campus for the SCNs. This academy was not only the oldest of the SCN academies but also its best known institution; here Carroll would spend her entire career. Nazareth Academy was one of the earliest academies established in Kentucky and quickly became an institution of some repute; the early age of its foundation meant that it was firmly grounded from the beginning in the academy movement. Early on, the school had established an excellent academic reputation. For example, Fr. Augustus J. Thebaud, author of Forty Years in the United States, 1837 1885 , recorded a conversation he had with a young husband in 1842 , on route to Louisville, KY from Louisiana:

He lived in the interior of Mississippi where he was the owner of a large estate...The young wife, being deficient in education... he had obtained her consent to go north to some educational institution, where she might spend a few years if necessary and gain some knowledge of music, geography, history, English literature. He wished to confide her to some nuns in Kentucky of whom he had heard, the Sisters of Charity of Nazareth.... All the young women of his vicinity who had been graduated from that convent returned home with a deep affection for their former teachers (205-208, qtd in McGill).

As Thebaud's example demonstrates, the Academy's outstanding reputation for producing young ladies of grace and quality of mind was well -known, especially in the southern regions of the United States.

Much of the school's reputation was due to Carroll's leadership. For example, one year after Carroll took the position as Directress, the school began advertising its curriculum in the Catholic Almanac, which was a step to draw society's attention to the 
growing school (Corcoran 20). The work to gain the academy proper notice must have been successful, as among the roster of students at Nazareth Academy were the daughters of newspaper editors, plantation owners, governors, and dignitaries, such as Zachary Taylor, Jefferson Davis, and Henry Clay (Mattingly 168). The Academy also drew students from all over the country and a few international students, as well as a crosssection of religious backgrounds, including Catholics, Protestants, and Jews (McGann Mother Columba 6). But it was also a school in transition. In the mid-1850s, the student population was mainly students ages 14-18 from middle-class to wealthy southern families, but by the end of the Civil War, the majority of the students came from the Midwest (Table 2). The number of students from certain states such as Mississippi would recover in the post-Civil War years, but the Academy would never regain its foothold in other southern states such as Louisiana.

In terms of enrollment numbers, Nazareth was one of the larger institutions in comparison to other female academies. The school reached one of its greatest enrollment peaks between 1855 and 1870 . The 1857-58 school year saw 202 students complete the academic year, with enrollment increasing significantly each year until the 1865-66 school year enrollment peaked at 369 students (Nazareth Academy Annual Catalogues). Enrollment would decline after this, but would hold steady for the next few academic years at approximately 310 students per annum (Table 2). Similar southern institutions, such as the Carolina Female School and Alabama Female Institute, saw enrollment figures in the 180s - 200s during the same time period (Kelley Learning to Stand 84). Female institutions that would later become some of the leading female colleges, such as Rutgers Female Institute, had enrollment figures between $100-200$ between 1840 and 
1860, making Nazareth's enrollment on par with to double theirs by the end of the Civil War (Kelley Learning to Stand 85; Nazareth Academy Catalogues). The SCN's other academies did not boast as high an enrollment as Nazareth Academy, and their demographics were also much different. While Nazareth Academy was clearly drawing from some influential southern families, the other $\mathrm{SCN}$ academies fit the generalization offered by Sizer and Leslie, both of whom have argued that the student demographics of most female academies represented the "rural middle classes" (Leslie 262). ${ }^{13}$

Economically, the students at Nazareth Academy were of sufficient socioeconomic status that a private education could be afforded, so it may be assumed that the students at Nazareth Academy were considered middle-class to wealthy. However, no extensive study has yet been done on the socioeconomic status of the female students at the various SCN academies.

While enrollment fluctuated from year to year, the leadership at the academy sought to ensure that the curriculum continually improved. The centennial history of the Congregation notes that the school aligned "with Matthew Arnold [who believed] that 'conduct is three-fourths of human life,' [thus] the faculty considered that in the cultivation of ideal Christian womanhood, attention to dignity and grace of demeanor, courtesy and consideration of others, was as necessary as training in academic branches; hence by continual discipline of precept and example, stress was laid upon these virtues"

\footnotetext{
${ }^{13}$ For more information regarding demographics in nineteenth-century academies, see Nancy Beadie's "Academy Students in the Mid-Nineteenth Century: Social Geography, Demography, and the Culture of Academy Attendance."
} 
(McGill 128). In her diary, Carroll quotes British moralist and best seller Hannah More's Coelebs in Search of a Wife ${ }^{14}(1809)$ that

I call education not that which smothers a woman with accomplishments, but that which tends to consolidate a form and regular system of character, that which tends to form a friend, a companion, a wife. I call education not that which is made up of the shreds of patches of useless arts, but that which inculcates, principles, polishes taste, regulates temper, cultivates reason, subdues the passions, directs the feelings and habituates to reflection, trains to self denials, and more especially that which refers to all actions, feelings, sentiments, tastes, and passions to the love and fear of God. (diary 247)

The focus here is clearly on developing the whole person, in training students to be active members in their society. Carroll's fear is that "the education of the present race of females is not very favorable to domestic happiness," (diary 247) and she seeks to ensure that Nazareth Academy does all it can to teach the life skills necessary for domestic bliss. In addition to the esteemed personal virtues that Carroll sought to instill in her students, the Academy also offered rigorous academic training. In 1826 , the curriculum consisted of basic subjects, such as reading, writing, arithmetic; ornamental arts such as tapestry, drawing, painting; logic; and advanced subjects, such as rhetoric and natural philosophy (Clippings for Annals 1, SCN Archival Center:1). By 1833, under Carroll's influence, the curriculum had expanded to include more branches of science, a common trend in northern academies but not exclusive to them. Kim Tolley argues that "although Catholicism was a minority religion in the United States, some of the academies run by

${ }^{14}$ Carroll notes in her diary that "I am reading H. More's "Colebs in search of a wife." I like her ideas on education" (15). 
various orders of the Catholic Church adapted to the newer American views of female education by offering scientific subjects to middle-class girls" ("Science for the Ladies" 139).

In terms of course offerings, Nazareth Academy is similar to other prominent academies on several fronts. While the advanced curriculum was not commonplace among all female academies, it was the norm for other female academies that had an equal standing and reputation compared to Nazareth Academy. Farnham notes that after 1830 common subjects could include "composition, logic, rhetoric, botany, natural philosophy, astronomy, chemistry, geometry, algebra, trigonometry, history, and moral philosophy" (50). The advanced curriculum drew concern from the SCN's Bishop and criticism from advocates of traditional education because it was outside the realm of the domestic, despite the fact that a growing number of female academies had more advanced science programs than those of male institutions (McGann Interesting Facts 4; Tolley "Science for the Ladies," 142-143). The contention over adding science instruction to the curriculum was captured in an 1827 letter to Rev. Simon Bruté from Bishop David, ${ }^{15}$ whose approval was sought in curriculum changes. He commented that "I did not approve the introduction of the four branches [sciences] that you marked, but our Mother insisted very strongly on the addition and her reasons were very convincing. The parents of the ladies desired that we teach sciences. That gives a certain prestige to the school and procures a greater number of boarders ..." (qtd. in McGann Interesting Facts 4). This hesitation over the sciences was not shared by Carroll, who would become the Directress

\footnotetext{
${ }^{15}$ Bishop Jean Baptiste David is considered the co-founder of the Sisters of Charity of Nazareth, alongside Catherine Spalding, the first Mother. His goal for the Order was to serve in education and fill in the lack of educational opportunities for young female Catholics. His influence in the community was very powerful, and he often offered his conservative opinion on the academy's operations.
} 
of Study a mere six years later. Carroll writes in her diary that "I but half fulfill my duty as teacher when I merely teach my scholars the principles of those beautiful sciences, Philosophy, Botany, etc. I should avail myself of all the Phenomena, etc. to lead their young minds and hearts to their Good and Beauteous God," (11) clearly indicating an enjoyment of science and familiarity with its various branches.

Despite some contention over adding new and advanced classes to the curriculum, what was agreed upon was that the changes in the curriculum increased the reputation of the school, bringing more students and allowing the SCNs to fund other projects. In the aforementioned letter from David to Bruté, David writes, "Do not think for a moment that I am losing sight of the education of orphans and other poor girls" (qtd. in McGann Interesting Facts 4). He goes on to discuss how the Sisters' bringing in more boarding students to the Academy leads to a greater increase in funds, which then would be used to fund their orphanages and free schools. The Sisters used the same argument to continue to expand the curriculum throughout the 1860 s to include more branches of classical education, including the addition of four more languages. ${ }^{16}$ The teaching of "female accomplishments" such as painting, embroidery, etc. remained in the curriculum but became listed as electives rather than core courses. Despite all the changes and development in curriculum, one consistent part of the curriculum was that "Lessons and Exercises in Polite Literature will also be given" (1858 Nazareth Academy Annual Catalogue, SCN Archival Center), which indicates a strong and consistent emphasis in the curriculum on literature. The initial emphasis on literature education can be attributed

\footnotetext{
${ }^{16}$ For more information on the expanding curriculum, see Table 3
} 
to Sister Ellen O'Connell, ${ }^{17}$ a rare woman, highly educated and a gifted teacher.

Appointed as the Academy's first Directress of Study, her emphasis on establishing a strong academic program remained a major influence over the school.

\section{Mother Columba Carroll}

Sister Columba Carroll replaced Sister Ellen O'Connell as Directress of Study in 1832. She was born Margaret Carroll, an Irish immigrant who moved to the United States at age six. Her parents died in 1823, leaving young Margaret and her sister, Sophia, orphans. At this time her guardian, John McGillyCuddy, placed Margaret at Nazareth Academy and placed her sister in a nearby academy run by the Sisters of Loretto (McGann Mother Columba 3). Despite how difficult this transition must have been for thirteen year old Margaret, she excelled both academically and socially (Krumpleman). She entered the SCN community at age fifteen and took the name Sister Columba Carroll. Her contemporaries noted that "she exercised a mild and firm authority quite wonderful for one of her early years" and that the "pupils wondered how one so lovely could turn her back upon the world and shut herself up in a convent" (McGann Mother Columba 3).

Carroll would spend the majority of her fifty years in the Order serving as a teacher and Directress of Study, a role that encompassed the running of Nazareth Academy, as well as teaching the pupils and the young Sisters and novices who would

\footnotetext{
${ }^{17}$ O'Connell was one of the first leaders in education at Nazareth Academy; she had received a unique education, the only child of a single, doting language and rhetoric professor who insured that she received an education most often afforded to males, with advanced training in language and literature. When she was a young teacher in Baltimore, she attracted the attention of Bishop David, who worked to convince her to join his fledgling community. From the time of her arrival at Nazareth until a disagreement between her and the bishop ensured her removal from the school, she was the Directress of Study, as well as head of training future sister-teachers. She regularly conducted classes, not only for the students, but also for her fellow faculty members at Nazareth and the young Sisters who taught at the other schools (McGann Interesting Facts 7).
} 
become teachers (McGann Mother Columba; Sister Permanent Record Card, SCN

Archival Center). In her role, Carroll was in charge for a period of over forty years in the education of every young Sister who entered the order, Sisters who would go on to careers in education, who as previously discussed, would move from academy to academy, which means Carroll's influence in SCN academies was quite extensive. It was in this capacity of Directress of Study that Carroll began writing educational texts for the young Sisters. Her pedagogical text was entitled On Education and gives an insight into what life was like in the academies run by the SCNs. As the Directress of Study, she would have managed the business of the school, as well as overseeing the development of the students and the teachers. She approved classroom curriculum, including developing the Academy's literature curriculum. Her literary curriculum was transcribed into a notebook so that it could be used by other Directresses of Study and aspiring Sisterteachers. The book is simply entitled Course of Literary Study.

In addition to writing texts designed for use by the Community, Carroll also kept a diary. Indications in her diary suggest that Carroll did not consistently keep this type of record, but the SCN archives contains parts of her diary from the 1840 s to the $1870 \mathrm{~s},{ }^{18}$ which is the majority of her tenure as Directress of Study. Carroll's diary is a valuable resource because it reveals how actively Carroll was thinking about pedagogy, as well as giving the reader access to her more private thoughts. It is also a valuable source for researching what authors Carroll was engaging with in her private reading time. Carroll often recorded what authors she was reading, but she also recorded passages that she

\footnotetext{
${ }^{18}$ Carroll wrote in books but also on unbound paper. Thus far, two different segments of Carroll's diary are available, one of which was discovered in a desk in the 1980s.
} 
found influential. The act of writing down passages was particularly important for Carroll, who writes

An idea has been suggested to me by the perusal of some books --- viz,. to acquire the habit of penning down miscellaneous thoughts. I like the practice well for several reasons: I believe it is often profitable to clothe one's idea in language. $1^{\text {st }}$, it helps us to retain a good impression which might otherwise be lost; $2^{\text {nd }}$, it induces a habit of thought and industry which greatly assists the formation of good character; $3^{\text {rd }}$, it may frequently prevent the loss of time and rid us of that love of idle, useless conversation, which is by no means uncommon; $4^{\text {th }}$, it cultivates a literary taste and improves our facility of expression; $5^{\text {th }}$, and affords a kind of spiritual as well as literary pleasure. Then by repeating the views and thoughts of others they become in some sort our own, just as by associating with persons of good and noble characters, our own partakes of these qualities, at least it is raised by the association; hence, a double advantage of pleasure and profit may be derived. (4)

Thus, by her own admission, when Carroll records a passage in her diary, it is for more than just remembering it. She finds that the act of recording a quotation makes it, in part, her own.

Carroll's legacy exists in large part because she was a very capable educator and administrator, taking advantage in an era that Kim Tolley calls the "hey-day" of the academies to increase the position of Nazareth, but also to improve and open other SCN academies and schools ("The Rise of the Academies" 229). Administering during the early years of the Civil War, Carroll maintained the daily flow and functions of the 
Academy as well as her entire Order. Tragedies such as the Civil War were devastating for many institutions but, during the Civil War, under Carroll's leadership, three hundred students were enrolled at Nazareth, and the number of Sisters increased significantly (Krumpleman). Carroll was elected Mother Superior ${ }^{19}$ in 1862, served until 1868, and was reappointed to the Academy from 1868 until 1874, when she was re-elected Mother (Sister Permanent Record Card, SCN Archival Center). During her tenure in office, she would build Sts. Mary and Elizabeth Hospital in Louisville with money donated by the spouse of one of her devoted former pupils, and would open additional academies and free schools. Carroll passed away on December 18, 1878, her death attributed to yellow fever. Frances Krumpleman, SCN notes in a text on SCN leadership that "because of her gentleness and loving, serene disposition, her years as an administrator were given the title, 'Rule of Love.' It was said that her exceptional spiritual qualities were ranked among the finest gifts God bestowed on the SCN community" (Krumpelman).

But more than being a capable administrator, Carroll was an intellect and teacher, highly interested in the development of her academy's curriculum and in serving her students. A study of her diary produces quotations from known female educators, especially Lydia Sigourney, reflecting on the state of education and what was necessary for improving the state of female education. The 1830 s and 1840 s was a critical time in female education, with educational advocates such as Sigourney, Beecher, Hale, Willard, etc. laying down a foundation of texts on female education. While it cannot be proved definitively which of the works that were being written regarding female education

\footnotetext{
${ }^{19}$ Mother Superior was the title of the leader/president of the SCN community. She would have directed all major aspects of Community life, as well as financial and business decisions. The title evolved throughout SCN history and now the head of the Congregation takes the title of President.
} 
Carroll read, the era was a period of active discourse about female education. At this time, Carroll was a relatively young educator who was actively thinking and developing her ideas about how female education should be accomplished. She was clearly interested in reading other key female educators, actively reading and keeping notes in her diary of passages that influenced her. As such, her diary and her text on pedagogy are both methods in which we can examine what ideas and whose voices were influencing Carroll's ideas on pedagogy.

\section{Carroll's Pedagogical Philosophy}

The most direct way to examine Carroll's ideas on pedagogy is to examine her guide on teacher education, which was entitled On Education in Boarding-schools for Young Ladies. Carroll saw this as her "last testament; in which I deposit my little treasure of experience" $(2-3) .{ }^{20}$ Carroll's purpose in writing it, she asserts, is to ensure that her Sister-teachers can care for the spiritual, as well as intellectual development of their students. But the text reveals aspects of Carroll's own exploration of female empowerment and relationships and her struggle with how those ideas are in direct conflict with the strict societal understanding of what encompasses the female domain. For example, in her section on relationships, she writes that the relationship between teachers and the environment of the female academy allows for the reevaluation of female gender rules and offers the possibility of living an alternate domestic narrative. The world that Carroll outlines for her young teachers creates an alternative vision of domesticity within the walls of the boarding school, a world where women had more

\footnotetext{
${ }^{20}$ The manuscript is undated. My assumption is that this text was written between 1871 and 1874 , which would place Carroll back in her role supervising novices, teaching, and also put her at a sufficient age to feel older, especially in light of the tremendous stress she experienced in her role as Mother Superior during the Civil War.
} 
room for intellectual freedom than within the confines of marriage; however, this empowering world of the instructress intersects with that of the pupils, young women who are entrusted to the SCNs to complete an intellectual and moral education which brings with it societal implications.

For the Sisters, the school would encompass the majority of their social network; thus Carroll felt strongly about the importance of community with other women and advocates this type of engagement among her teachers. Carroll sees her environment as a world of institutional education run by and for women. She uses the depiction of the end of the day, where all the Sisters are gathered together, everyone sharing from her own interests and knowledge. Thus, the whole group grows intellectually and can share more deeply thoughts about politics or the state of the world (On Education 6). Carroll describes a night sitting around the fire where they can ...converse on history or read some pages of literature. Generally speaking, we politely shun our Mathematicians; but the Botanist who displays before our charmed eyes, some plants hither to unknown, which she has just analyzed... the poetry modestly read by the fair authoress, the musical composition, the landscape or flower painting... the languages too lend their charm... Thus we have the privilege of perfecting ourselves, from the diversity of gifts and talents of our Sisters. (6-7)

This passage is clearly a depiction of domesticity, with the gathering of the members of a household at the fire to share conversation. However, in this domestic ideal, there is no husband and no children. It is a female domesticity with females encompassing the role 
of the family, and it is an intellectual exchange where joy is gained from the exchange of ideas.

This passage also indicates that Carroll and Nazareth Academy have succeeded in something that Catharine Beecher continually advocated for and often was unable to see realized: specialized teachers who only taught subjects within their area of interest or expertise. The idea is that the specialized teacher would provide a better education for her pupils because she was only teaching within her specialty, but also would relieve some of the intense pressure on teachers to be proficient and teach all subjects. For Carroll, no one person can know everything in terms of academic information, but it isn't necessary since there is a community of knowledge to draw upon. Thus, the Sisters are entering into an alternative domestic narrative, where a female intellectual is allowed and encouraged to blossom. It also means a greater opportunity for her teachers to engage intellectually with one another, with ample opportunity for personal growth through community. It is clearly directed toward Sisters, but Carroll notes that she also admires women lay teachers, and this joy can be shared by all women who share the common calling of teaching (9).

Community is a theme that Carroll returns to over and over again. It is easy to assume that Carroll enjoys communal living since she made the choice to embrace living in a convent over choosing marriage or seeking a life on her own. Carroll argues that community provides an opportunity for intellectual growth and exchange, as illustrated in the passage above. However, outside the communal nature of the school environment, Carroll ensures that the individuality of her teachers is not neglected. She writes that there are certain duties that each teacher must perform for her own benefit, since the 
growth of the individual adds to the healthiness of the whole. The definition of a good teacher is a woman with the following characteristics:

.... a sound head is indeed requisite!- An Instructress, endowed with good sense and tact; who knows how to appreciate things according to their just value is to be admired. She sees things as they are; she comprehends what she hears, she takes terms in their natural and true acceptance. Gifted with perseverance, and being solicitous to perform well her duty, she remains in her own sphere of action, embracing all that appertains to her department, and considering of it a positive and practical light she understands that hers is the domain of real life; and she is not deceived by fiction, no matter how beautiful it may seem. (18-19)

In order to ensure that each instructress reaches her highest potential, Carroll instructs that each day the teachers are to take a mental inventory of their own accomplishments. Reaching one's potential requires a great deal of self-awareness and self-control, as Carroll writes that "we must pass within ourselves, when we are, so to speak, obligated to read in our own interior, to discuss the merits or demerits of our work" (9). Carroll embraces this discipline in her own life, writing in her diary that she would be working on "Spanish and Italian alternatively each day devoting a couple of hours to one or another"(13). These languages had recently been added to the curriculum, and Carroll was ensuring that she knew both languages, despite not being a foreign language professor and already being fluent in French, and was keeping her mind active. Carroll notes that this type of mental evaluation might be agreeable or disagreeable, but constant self-awareness is critical and allows for the development of better teachers. Thus, the 
instructress is allowed to share in the joys of communal learning, but this must be balanced and tempered by self-improvement and self-awareness.

The two elements of community support and personal intellectual development provide a way for the instructress to deal with the trials associated with education. Much of Carroll's concern throughout the text is in preparing her young teachers to deal with the hardships they will encounter, but also teaching them to prepare their pupils for future trials as well. Carroll addresses six trials young teachers will face: the main trial will be their own nature and frustration that occurs when a teacher feels like she isn't accomplishing her goals; the second struggle is the battle with students over their ignorance, bad behavior, and general lack of adult reasoning; third is dealing with feelings of failure; fourth is outside factors such as prejudice against Catholicism, jealousy of others, and, perhaps worse, criticism from those whom a teacher may hope to receive encouragement from, such as priests; the fifth trial is a pupil's parents and their unreasonable complaints and inability to control their children, the unrealistic expectations of parents and the community upon the Sisters and the school; and, finally, the way that work wears upon the soul and the general hardships of life (12-13). So how does the teacher deal with the difficulties of teaching? According to Carroll, the teacher must learn to practice the "Christian philosophy" of "Resignation" (11). Acceptance of circumstances and the theme of resignation become essential to Carroll's argument of how instructresses achieve happiness and the key lesson that they must pass on to their pupils.

Carroll places the emphasis for student's moral development on the teachers, which leads to a questioning of what is the role of parents within Carroll's pedagogy. At 
a time when the dominant culture portrayed the mother as the great educator, often picturing her sitting down reading to her children, who are gathered around her feet, Carroll shows a different side to this portrayal. She argues that parents can often be one of the barriers to providing a solid education, and that parents sometimes fail to educate their daughters. Instead, Carroll argues, parents often wait until their children go to boarding school, expecting that boarding school will develop the child's character. However, by this late age it may be too late, and the child has been neglected far too long. Religious education and good guidance can train the child to be better, but it will require much more effort from the instructress (118-120).

In order to produce scholars of a good moral character and deal with the pressure of this responsibility, Carroll encourages her teachers to be joyful and happy. She calls on her instructresses to remain young at heart, encouraging them to laugh and enjoy simple pleasures and amusements with their pupils. By keeping their hearts young, teachers are better able to remember the joys of education and service to God. This will also help to keep teachers from getting discouraged. Moreover, she argues that instructresses should approach teaching with the same joy that they find in their religious life. By advocating for a school of laughter and joy, the teacher can share a positive atmosphere with her pupils. The desired result would be a school filled with smiling, happy pupils and teachers, which stands in contrast to the harshness of the world.

Carroll, like other educators in her era, was concerned with the social hierarchy that would face her pupils. She faces the hard task of teaching teachers the art of encouraging their pupils to dream and find happiness in their life, while trying to balance the expectations for young women to face the era's harsh reality of female life. This 
reality often has to be first understood by the teacher herself. Carroll begins her text with an outline of the qualification for being a great teacher, which includes a vocation for education. Carroll writes that this vocation may be a natural talent that drives the person towards education, which Carroll sees as her personal experience. However, while other educators such as Beecher believed that all women should be teachers before taking their place as wives, Carroll realistically knows that not all women, even women within her order who entered a teaching community, will feel called to serve as teachers or even enjoy the role. She writes how when she was a five-year-old she played teacher, trying to teach her playmates as well as the workmen she knew to attend her imaginary school (5). However, not everyone who finds herself a teacher has a deep desire to educate but rather "teaching becomes a necessity." This is where the harsh reality of female life steps in, the reality that teaching is one of the few jobs available to women.

Learning to be satisfied with one's situation and developing resignation offers a certain comfort to those women who find themselves working as educators yet do not feel it is their vocation. These women are not doomed to a tragic life, however, as "happy are those who know how to make of this necessity a virtue" (5). This was often the case, as young Sisters found themselves in educational roles, since the primary role of the Sisters was the education of women. However, Carroll often had to explain to parents and students alike why Sisters made the choices they made, to withdraw from their families and social world and to pursue their ministries in education. Carroll writes that people felt the Sister's "secluded and laborious life is an enigma, and [she is] often asked to explain it. My reply is: 'we were told that the education of youth, especially of girls, was sadly neglected, throughout the country, because competent teachers could not be found; and 
we offer ourselves to God, for the glorious task of instructing and educating young persons of our sex" (6).

Carroll also encourages her teachers to find ways to teach the students how to find satisfaction with their situation, while also instructing the teachers to create equality among female pupils. Each boarding school, but especially Nazareth Academy, which was run directly by Carroll, would have been composed of girls from different geographical regions, backgrounds, and socioeconomic status, which the students often broke down into a social hierarchy, similar to the way that a high school hierarchy may operate today. Catharine Beecher saw this social hierarchy as the way that God created the world, in which all people have equals, superiors, and inferiors, and by locating and finding satisfaction with one's place in the world, one can grow closer to God. However, Carroll actively discourages her students and their teachers from allowing the creation of a social hierarchy. She also argues that sometimes the teacher has to break down the hierarchy by not rewarding students, even if the student deserves the honor. For example, if a girl is the best actress in a class, the teacher should not always give her the lead part (49).Carroll views hierarchy as a symptom of pride, which is ironic for a Catholic, but this irony is never addressed by Carroll.

The complicated relationship between the teacher and the pupil extends past this issue of hierarchy among students to encompass all interactions between the pupil and the instructress. Carroll wants her teachers to be in control of their classrooms, to command the respect of their students. She warns her young teachers that if they are not in control, then the students will find one among themselves who will become the leader of the class (51). The teacher will then have failed to control her class, as well as failed to keep a 
hierarchy from forming among her students. However, Carroll's text on pedagogy is not all warning or about breaking social norms among students.

When reading Carroll's text, one becomes aware of her obvious regard and good wishes for her young Sister-teachers and their pupils. Carroll's letters and diary indicate that she was absolutely devoted to her pupils and became lifelong friends with many of them. Her task and duty as an educator was essentially to empower her students, grant them the fortitude and strength to be what society expected of the educated, nineteenthcentury woman, while at the same time preparing them to understand the challenges that they would face. Her job was to empower women to be understanding and find ways to happiness by living a secondary and under-powered role in their society. This is likely why Carroll was so insistent that the school be a place of happiness and female companionship; once her pupils left the female domain of the school, their roles would become those of wives and mothers, and the communion with other women would become limited to letters and the occasional visit. School might be the only time in her students' lives when they were allowed to express themselves.

But Carroll also struggled with the domestic world that she was preparing her students to embrace. Her diary indicates Carroll may have even struggled with respecting the role of the domestic, especially in contrast with that of the intellectual world of the teacher. She writes "Genius has pleasure enough in its own great blossom of talents. I agree that it is better to thin the blossoms that the next may thrive, and that in encouraging too many propositions, one faculty may not starve another. There is no great merit in being able to manage a house or family, but to be unable is highly indiscreditable" (diary 16). But that sentiment could hardly be one that Carroll could 
acknowledge in public. Her role was to train women to be good wives and mothers. Carroll's complicated text shows a woman either struggling internally or guarding herself externally from a duality that was perhaps too radical to safely explore.

The possibility that life as a Sister and as an educator offered women the chance to explore a new or different life, one free from the societal expectations of matrimony and childrearing, is checked within Carroll's text by constant reinforcements of societal norms and reassurances that the traditional notions of domesticity could offer joy. Carroll's pedagogy is focused on the whole person, whose moral development is as central as the intellectual development. Her desire to create a feeling of equality among her students is checked by the reality that the world they would occupy was hierarchical, because they were women, and because that was the manner of the world. Much of Carroll's text, On Education, is focused on the need to teach students self-control, stating that the role of the woman is to graciously yield in all situations, unless it goes against her consciences. This is taught so when the female child becomes a woman, she can bend without breaking, and the mockery of others will not tempt her to abandon her cause $(\mathrm{On}$ Education 31-34).

The implications outlined in Carroll's text illustrate that ideas regarding women educators and female education of her era are complicated and open the door a little further for us to explore the foundations of female education. Her text becomes a study of contrast, allowing us to see a woman that questioning societal norms and the ideology of motherhood in this country, but with words tempered by internal desire to conform to societal expectations or the reality of what such notions would mean to the future of the Congregation and academies she cherished dearly. 


\section{Literature in the Classroom}

In addition to her work on pedagogy, Carroll was also keenly interested in the role that literature played in her school, and to that end she created a literature teaching guide to ensure that her literature curriculum was followed closely. She served as head teacher at times in literature or compositions classes. ${ }^{21}$ However, her passion was for teaching literature; in her diary she bemoaned the heavy burden of teaching composition: "Oh, that pile of composition books through which I am to wade. They rise above me like Macbeth's ghost, to overcloud this pleasant leisure hour" (diary 293). Her praise often focused on a student's temperament and literary tastes. For example, when speaking of a beloved student, Carroll notes that "she is so sincerely pious and unworldly. And she is literary too, which is far rarer than persons think, in our times of books" (diary 292). As for official, academic recognition, every year those graduating students considered the most advanced readers and those who had superior taste in literature were awarded the highest prize at Nazareth, the Crown for Superior Literary Merit. Graduates were "expected to be distinguished by zeal for study, promptness in attending their various duties, and excellence in the manner of reciting and performing each duty. They are to cultivate a love for reading and all such pursuits, as will aid them to merit the crown for superior Literary Merit" (diary 290), though this standard was expected of students who were not graduating. Students also showcased their parents their ability in parsing poetry, most particularly John Milton's Paradise Lost (Nazareth Academy Annual Catalogue).

However, for Carroll, literary education was more than part of a solid education. She was a passionate and prolific reader, and her diary frequently noted what texts she

\footnotetext{
${ }^{21}$ There is evidence in Carroll's correspondence that she did not create a text for teaching composition. In 1870, Carroll writes to Sister Eulalia Gaynor and requests an order be placed for two dozen copies of Vinner's Guide to Composition be sent to Nazareth Academy.
} 
was engaged with, as she used the pages of her diary to record passages or ideas encountered during her reading. She saw reading as a way for her female students to find entertainment, engage in the world, and push their intellectual boundaries. She also saw it as a way for her students to escape from the limitations of the domestic world she was preparing them for, a manner to engage outside their confinement to the home under the rules imposed by the gender norms of the mid-nineteenth century. Carroll quotes this passage in her diary from Lydia Sigourney's popular advice book Letters to Young Ladies, 1837:

A taste for reading is important to all intellectual beings. To our sex it may be pronounced peculiarly necessary. It is important to all, because it is the way in which aliment is conveyed to the mind, and to our sex peculiarly necessary because dwelling much on the contemplation of little things, they are in danger of losing intellectual appetite. A taste for reading is therefore to them an armor of defense. It is also a resource where the world reveals its emptiness, or the things of the world confess their inability to satisfy the heart. Men go abroad into their busy current of life, and throw aside their chagrin and disappointment and lose the narrowness of personal speculation in its ever fluctuating tide. Home, the woman's province, admits less variety. She should therefore, diversify it by an acquaintance with the world of intellect, and shed over the freshness derived from the exhaustless fountain of knowledge. The love of books is also a preface in those seasons of indisposition, when active duties are laid aside, when conversation is a burden and that gaiety of heart which was as sunshine to life's landscape has taken flight. (diary 258) 
Carroll's choice of Sigourney's words captures perfectly what Sicherman argues in WellRead Lives, a study that examines "the ways in which reading stirred imaginations and fostered female ambition... that reading had long been an important vehicle for promoting and sustaining women's aspirations and that it had a special resonance for young women in the years after the Civil War" (1). Thus, for Carroll, it was almost a moral obligation to instill in her pupils a love of literature because this love of reading would sustain their intellectual and moral development for their entire lives. Moreover, her belief that literature allowed for variety in a woman's domestic sphere meant that she would teach widely diverse genres of literature, including the novel.

Scholars have long contended that, while it is known that young women were reading novels, they were not taught in the academies. Christie Farnham argues that "novel reading was deplored, but few students were dissuaded, despite efforts to frighten them away from the activity" (74). Critics and educators alike have argued that fiction represented, to social commentators, an unwise use of literacy, wasteful to the individual and harmful to society. Novel-reading was pernicious; novels made few appeals to the intellect and they were habit-forming. Good men did not write novels; therefore, good men and women should not be their readers. Not only threatening to thought, intelligence, religion and morality, 'no dissipation can be worse than that induced by the perusal of exciting books of fiction...a species of experience of a monstrous and erroneous nature.' The danger was perhaps greatest to young unmarried women and to children, whose innocence it was most important to protect (Graff 296). 
Likewise, Susan Griffin argues that "the history of the novel in particular is deeply imbricated with advice for, fears about, warnings to educators, parents, girls themselves. Fiction was considered especially dangerous for women who were thought to be, by their very natures, more sensitive, emotional, and empathetic-and thus more susceptible to sensational influences" (1). ${ }^{22}$ Griffin goes on to cite Frances Willard, a highly influential educator, who argued against young women reading novels in How to Win: A Book for Girls, claiming that "Much as I disliked the restriction then, I am now sincerely thankful that my Puritan father not only commanded me not to read novels, but successfully prohibited the temptation from coming in his children's way" (qtd. in Griffin 1).

Despite these quite vocal stances against women's reading fiction, scholarly evidence supports the reality that women were not only avid consumers of fiction, but also in the forefront of its production. Nathanial Hawthorne's famous quotation that "America is now wholly given over to a damned mob of scribbling women, and I should have no chance of success while the public taste is occupied with their trash--and should be ashamed of myself if I did succeed" is a reflection of the huge number of female American writers. Essentially, women wrote fiction and they bought the novels, but did they study it in the classroom? This question is not centered on whether female students were reading classics that were considered part of the literary canon of the time, but were they reading the popular novels of the era? If so, were they reading American or British novelists? Were they reading female writers, or strictly male writers? Carroll's literature curriculum affirms that, at least at Nazareth Academy, female students were indeed reading fiction, and allows us as scholars to examine what fiction they were being

\footnotetext{
${ }^{22}$ The citation for Griffin is based on a manuscript draft provided by the author, not the published version.
} 
introduced to in the classroom. But more than reading fiction, these students were also being exposed to politics, classicalism, poetry, and women writers. The inclusion of a literary text in the classroom has the implication of acceptance of the text as a higher form of art, culturally coding the text as being not only for pleasure, but also as beneficial for the most vulnerable members of society, i.e. impressionable, young female students. However, because of societal belief that young, female students were among the most vulnerable members of society, what was present and not present in Carroll's literature guide helps fill in the gaps in our understanding of what female students were reading, at least in the context of Nazareth Academy. The question of what were these women reading will be explored in the next chapter. 


\section{CHAPTER 2}

Carroll's literary curriculum was designed for private and practical use within Nazareth Academy, instead of publication. The curriculum is recorded in a plain green and white notebook, handwritten, with a simple label of Literary Studies. The inside front cover of the book notes S. Marilla's name, and below it says, "This book was prepared after Mother Columba's method - who used it teaching literature. Miss Mary Scollay copied the lessons. The method with little variation was used by Sister Marilla." Mary Scollay was a Nazareth Academy student from November 1865 until June 1871 (Nazareth Academy Student Records, SCN Archival Center), indicating the time period that the book was transcribed. However, we can assume that the text reflects Carroll's years as a Directress of Study and a program that she developed over time. The text has two key sections, European writers and American writers, and within those two sections, authors are arranged chronologically, divided by genre. For example, Carroll listed the genre heading or category of "Histories," and the entries under that are the major historians of a limited time period, such as the seventeenth century.

Carroll was clearly actively thinking about her curriculum as evidenced in her diary. Her personal writings from the 1840 s reveal that Carroll was reading a large number of the authors she would incorporate into her text twenty years later. One example is that of Brownson, of whom Carroll writes that

Brownson's number for January is excellent. He is still free and independent, but it seems to me less boastful. There is now pervading his writings a tone of dignity 
and fearlessness, blended with Christian humility and charity that embellishes his profound erudition. In the beginning of his writing as a Catholic, there seemed always to my mind, something of the vain glorious and bitter tone that too often distinguishes the best protestant writers. Then, I admired his genius, now I yield my heart's homage to the noble humility with which he uses that strong and clear intellect. (67)

Carroll's diary provides evidence that she was discovering writers she admired, following their development, and thinking critically about how an author was changing over time. This being noted, Carroll's profession of admiration for an author in her diary is often tempered within her literature curriculum. While being profuse in her enjoyments of Brownson, Carroll later only briefly discusses his work in her literature curriculum, which will be examined later in the chapter. Thus, Carroll's diary not only gives evidence to how Carroll was thinking about certain literature texts, but also ways in which she chooses to temper her personal feelings when creating her literature curriculum. ${ }^{23}$

An examination of her curriculum reveals trends, some of which are indicative of the national trends in female education, and others which appear to be more atypical. While this chapter examines those trends, the discussion often returns to three key characteristics that Carroll consistently emphasized. These characteristics are noted in Carroll's introduction, in which she writes that "Chaucer was the representative, the epitome of the moral, religious and political ideas of the time in which he lived" (iv). Carroll thus places an emphasis on writers' political ideas/careers, their religious ideals or

\footnotetext{
${ }^{23}$ Brownson visited Nazareth Academy on February 2, 1854 to lecture the Academy girls and the male students at St. Joseph College. Carroll writes in a letter to Mother Frances Gardiner that Brownson was very positive in his review of the Academy, but that both the Academy girls and the College boys were disappointed in the quality of his lecture.
} 
lack thereof, and whether writers and their texts have moral themes. Carroll does not comment on these three characteristics in every single author, but she returns to these traits over and over again, especially if she notes that an author lacks a moral lifestyle. For instance, when writing about Sir Roger l'Estrange, Carroll notes that "In his writing he displaces a kind of vulgar wit much in favor with some classes, but the celebrity an author attains in this manner never endures, being ephemeral in its nature. In a prose paraphrase of Aesop's fables which he published, he indulges greatly in pert language" (21). Carroll does not comment on any political or religious themes in l'Estrange's work, but discusses his style and why it is popular, then clarifies her objections to the content.

The emphasis on moral characteristics is not surprising, considering Carroll is a Catholic Sister, and she is educating female students whose parents likely favored a more conservative education. Conservative literary preferences would seem to align with norms in female education; as Susan Griffin argues, "women...were thought to be, by their very natures, more sensitive, emotional, and empathetic-and thus more susceptible to sensational influences [such as novels]" (1). Carroll is aware that the Sisters are the main source of moral education for their pupils, writing that "The Sister of Charity should never forget she teaches, or should teach as much by her example as through books. Much more care should we give to the moral training since these lessons refer to the soul which will live forever. Oh! That I may never lose sight of my serious obligation and responsibilities"(diary 7). Her concern is also reflected in her text On Education, where she encourages teachers to be aware of their influence over their pupils. This being stated, Carroll still includes writers in her curriculum whom she considers questionable, indicating that she did not believe in hiding objectionable writers from her students in the 
hopes that lack of awareness would keep them ignorant, and as such, innocent. Instead, Carroll approaches these writers with her honest voice, often acknowledging their works and the reason for their inclusion, but not hesitating to also note what she believes are flaws in personal character or texts.

After establishing an early emphasis on the moral, religious, and political, Carroll moves to introducing different genres to her students. The variety of works that she includes in her curriculum are broad, but central in her curriculum is the inclusion of popular fiction, poetry, and religious texts, while also incorporating female writers, classics and political ideas. Her selections seem to be based on her perceived academic value of a text and/or on the perceived influence of a text or genre. Poetry, for example, was considered an essential part of female education, but popular fiction may be included because Carroll not only valued the genre, but feels it is too widespread among young female readers not to be included in the classroom.

\section{Popular Fiction}

That Carroll believed novels and popular fiction were too influential and prevalent in the lives of her students not to be read and enjoyed is likely, but Carroll also finds academic value in these texts. She comments that "The department of English literature which has been cultivated during part of the last, and part of the present century, with the greatest assiduity and success, is undoubtedly that of prose fiction - the romance and the novel" (88). The inclusion of a text in an academic setting has the cultural implication that there is something about the text that has value, that the consumption of the text is worthy of one's time and intellectual activity. As such, the inclusion of popular novels in her curriculum serves as a way to validate these works. 
When discussing these categories of writers, Carroll does not differentiate in her curriculum between those whose work is published in serial form, in magazines, etc., or as books. One reason for this is that poems and texts that were published in periodicals made up a part of a gift/ exchange economy in the schools. Histories of the school note how students brought Carroll poems and texts that were sent to them from their families. Carroll's former pupil, Eliza Wilkerson, recalls, "I received from my own sister, in a letter, the beautiful poem, 'Evening Prayer in a Girl's School.' Mrs. Heman's poems had not yet been published in book form, and this was from a paper. Oh, the happiness of taking this to Sister Columba and seeing her eyes beam with pleasure as she read it" (qtd. in Corcoran 20). The event that precipitated her student's bringing Carroll the poem was that the student had said something cruel and was grateful for Carroll's gracious handling of her crime. Thus, the giving of periodical publications or the texts contained within was seen as an acceptable way to express gratitude or share joy.

Carroll was not only given these texts as a gift, she also encouraged parents to send their children periodicals as a way to encourage reading without the implication that they were studying. In an 1855 letter to Dr. F.R. Alpuente of New Orleans, Carroll recommends that

If you are acquainted with any good literary magazines in French, it might be well to send it regularly to Matilda. Her studies are principally pursued in English; something of the kind would interest her more than books, and while seeming a recreation, would improve her in French. There are some now published in English which are highly improving to the young and awake in them a desire for 
information. I am not, however, aware of any in French. (Carroll Collected Letters V. I; qtd. in Corcoran 22)

Carroll recognizes certain periodicals as having intellectual qualities, but also that students find them more accessible than books. As such, these periodicals serve as an excellent way to educate students without the students realizing they are learning.

Another reason for including texts published in periodicals is that many popular writers were first published in serial format, and the text was then reissued in bound editions. The lack of differentiating between fiction published in periodicals and books indicates an academic acceptance in Carroll's school for serialized fiction, as well as essays and works that were published in popular magazines. Carroll even mentions particular works that were published in serial form as part of her notes on an author, such as when writing on William Makepeace Thackeray, an author she seems to admire, or at least whose work she sees as significant. She covers a variety of his work, ranging from his novels to his work in magazines, and under the various pen names under which he wrote (Literature 93-94). The acceptance of these printing media also gives Carroll more freedom for the inclusion of female writers, who comprise a significant portion of the popular novelists that Carroll covers.

Popular fiction was abundant, and Carroll notes in her own words that "This subject is so extensive, that the most feasible method of treating it will be to classify the authors and their productions" (88). In order to accomplish this, Carroll divides the European popular fiction into four divisions: "Romances," described as "works of narrative fiction embodying periods of ancient or middle age history (89)"; "Novels of Real Life and Society," which are about "the vast class of pictures of society, whether 
invented or not (89)" and being "generally novels, that is, tales of private life, though some, as those of Godwin, may be highly imaginative and even tragic... this class contains a great treasury of what may be called pictures of local manners, as of Scottish and Irish life."; the third group is "Oriental Novels - a branch almost peculiar to English fiction"; and the fourth category is "Naval and Military Novels"(89). Carroll only briefly covers the last two categories, leading the reader to assume her preference is for the first two.

The romance ${ }^{24}$ and real life and society texts include those written by several male writers, though the primary focus is on female writers. Carroll has mixed feelings regarding these novels, as illustrated in her critique of Horace Walpole. He is described as being politically incompetent and hiding away in his castle to write "with malicious assiduity in his vast and brilliant correspondence, the absurdities, follies, and weakness of his day." One of her main arguments against Walpole's work is based on his portrayal of female characters. Carroll calls his heroine "one of those incongruous contradictions, which are met in all the romantic fictions before Scott" (90). This line of argument arises several times, especially in regard to romance novels. Carroll does not like silly female characters nor does she enjoy texts that lack character development, and she finds male and female writers equally guilty of these literary crimes.

\section{Popular Literature and Female Writers}

Of particular interest is the high number of female writers that Carroll believes are worthy of inclusion in the classroom. One result of integrating popular fiction into her

\footnotetext{
${ }^{24}$ It should be noted that Carroll differentiates between romance novels and "Romances." The novel, according to Carroll was divided into two "correlative branches" (42) - the Romance and the Novel. She states that, in reference to the novel, "the English have few rivals and no superiors" (42). For Carroll, the Romance has only one superior writer, and that is Sir Walter Scott. He attracts more coverage in her text than any other single author, except William Shakespeare.
} 
curriculum is that it gives Carroll a chance to let her students explore and see female writers as valid authors within an academic context. By extension of including female writers in her curriculum, Carroll may be establishing female writers on the same plane with male writers.

Carroll states a preference in her diary for female writers, but she uses the same critical gaze when examining their works as she does male writers. When writing about Clara Reeves, for example, Carroll contends that Reeves' work Old English Baron contains the same defects in character development as many romance novels. Carroll compares her to Walpole, claiming Reeves' work has the same flaws but without the beauties of Walpole's "haunted castle." Even in regard to Ann Radcliffe, whom Carroll proclaims to be the master of the romance novel, she is both complimentary and harsh towards the writer. In reference to Radcliffe's two greatest works, The Romance of the Forest and The Mysteries of Udolpho, Carroll comments that Radcliffe's total incapacity to paint individual character, only makes us the more admire the power by which she interests us through the never failing medium of suspense. Her personages have no more individuality than the pieces of a chess-board, but the skill with which the author juggles with them, gives them a kind of awful necromantic interest. The great defect of Ann Radcliffe's fiction results from the unfortunate principle she had imposed on herself, of clearing up at the end of the story, all the circumstances that appeared supernatural. (90)

Carroll's argument is that what makes Radcliffe's texts enjoyable are the elements of the fantastic and the supernatural, but maintains that the problem with the genre is the character construction. 
Carroll includes Mary Shelley in this category of romance writers. She describes Frankenstein in great detail but includes no commentary or critique of the work, making it impossible to know how Carroll viewed it. Her inclusion of Shelley could be based on Carroll's appreciation for the supernatural, but the supernatural/ fantastic elements within Frankenstein are of a much different nature from those in Radcliffe's works. There are no ghosts or swooning heroines, and Shelley's text has the character construction that Carroll feels is lacking in other romances. It is possible that Carroll is simply unsure of how to approach Shelley's work. She obviously desires including the text in her curriculum, and, while Shelley's work does not fall in line with the other romance books, it does fit in this category more than the other categories.

The second category of popular fiction is "Novels of Real Life and Society" (92). Another category dominated by female writers, this genre includes: Frances Blarney, whose "chief fault is [an] affection of delicacy and refinement" (92); Mrs. Charlotte Smith, whose work is described as "pathetic" (92); Mrs. Elizabeth Inchbald, whose two novels "obtained much celebrity in their time" (92); Mrs. Amelia Opie, whose novel The Father and the Daughter "may still be read with interest" (92); and Lady Morgan and Lady Blessington, ${ }^{25}$ who have no commentary associated with their names.

The above mentioned authors have little if any commentary in Carroll's text associated with their work. The primary writer of interest in the "Novels of Real Life," as determined by the amount of coverage received, is Maria Edgeworth. Carroll praises her works highly, then in her curriculum lists an extensive sample of Edgeworth's published texts. Often, the more that Carroll likes an author, the longer is the list of her works that

\footnotetext{
${ }^{25}$ While Carroll does not talk extensively about Blessington in her curriculum, there is a very large passage in her diary from Blessington's Victims of Society.
} 
she gives to her students. Carroll claims that Edgeworth's early works are "written in a simple style, and the sound practical principles they inculcate, make them pleasing even to the adult reader." She describes some of Edgeworth's work for children as "masterpieces of style and reception" and states that Edgeworth's "writings display much common-sense, and to the young she has proved herself a valuable friend" (95). Carroll also makes a point in commenting that one of the key reasons she enjoys Edgeworth is the emphasis she places on the Irish people. Carroll writes that "Many of Miss E's works show a delicate appreciation of the merits and weakness of the Irish character, and she has in some sense done for her countrymen, what Scott did for the Scottish people" (95). In light of the rampant anti-Irish sentiment in post-1840s America, due to the large number of Irish immigrants seeking to escape the potato famine, Carroll is giving her students a more positive image of the Irish. The reason for this likely stems from Carroll's own background since she was the daughter of Irish immigrant parents.

Carroll concludes the category with another sampling of female writers that includes: Jane Austen, who "depicts the interior life of the rural gentry of England" (95); Miss Ferrier, who "has also written novels, but they are inferior to those of Miss Austen" (96); Mrs. Trollope, whose work "describes the stratagems employed by the pretenders to fashion" (96); and Miss Mitford, whose work is written with "much grace and delicacy" (96). Though Carroll chooses to explore European female novelists, she takes a different approach when integrating American female writers into her curriculum.

With American female writers, Carroll chooses to focus on popular domestic writers. Carroll places domestic writers in the same genre as journalists and educational writers, saying that the most "prolific branches of literature in America... [are found in] 
journalism and educational works [but] there is also a phase of our literary condition, equally significant: viz: domestic reading - a species of book intended for the family, and designed to teach science, religion, the love of nature, $\&^{\mathfrak{c}}$ " $(105)$. She defines the key authors of domestic literature as: Catharine Sedgwick, Lydia Child, Hannah Adams, Mrs. Lydia Sigourney, and Miss Leslie, sister of the artist (105). Carroll clearly differentiates between educational works and domestic works, even though both are educational in nature. Though Carroll does not state why, the difference could be audience, with domestic literature intended for the family circle (105) and the educational work for educational institutions.

The inclusion of domestic fiction aligns with the reason that Carroll admires Edgeworth: she admires practical and moral writing. However, Carroll encourages her students to read not only these authors' fiction, but also their poetry, short stories, and their domestic manuals. The significance of this is two-fold. First, it supports the claim that Carroll was actively reading and knowledgeable about what other female authors were writing about pedagogy and domestic life, as some domestic authors were also very influential voices in education. Secondly, the inclusion of the domestic manuals into her curriculum aligns with a national trend in female education that promoted the study of the sciences. Kim Tolley, in "Science for the Ladies, Classics for Gentlemen: A Comparative Analysis of Scientific Subjects in the Curricula for Boys and Girls Secondary Schools in the United States, 1794-1850," writes that:

Historians of science have frequently noted the rapid entry of women into scientific fields in the United States in the latter half of the nineteenth century. Heretofore, explanations of this phenomenon have centered either on the 
extracurricular scientific literature increasingly aimed at female audiences during the late eighteenth and early nineteenth century... scientific curriculum was widely implemented in schools for American girls from the first decades of the nineteenth century. The science education of American girls in the ante-bellum period thus constitutes a likely and heretofore overlooked factor in the rise of science as a female interest after the Civil War. (Tolley 153)

Science was encouraged for young females because it was thought to make them more informed wives and household managers.

Likewise, Carroll's inclusion of domestic manuals was a way of approaching the domestic academically by teaching practical skills. These practical texts were also texts that a woman could refer to throughout her domestic life. By exposing her students to such practical texts, Carroll is also advocating for a commonly held belief that education was a continual process to follow the end of formal education. Domestic literature allowed for the continued intellectual development needed to be a cultured female, wife, and mother (Sweet 43).

\section{Classics}

Carroll's curriculum fits well within the context of Tolley's argument regarding the inclusion of scientific texts. However, Tolley's argument also centers on contrasting the scientific emphasis in female academies to the emphasis on classics in male academies. While this may have been the norm, classics did influence Carroll's curriculum. Laced throughout her text are authors such as Lucian (13), Horace (25), and Virgil (37), though these authors are interspersed in unusual locations throughout the text. The randomness of their dispersal is noticeable because the majority of the texts in the 
curriculum are arranged in chronological order by genre, but the classical authors are not located in the beginning of the text. Instead, they are placed outside the genre and chronological limitations placed on the other authors.

This placement supports the argument that classics were not the main thrust of female education, but their inclusion also means that Carroll had exposure to and knowledge of the classical poets and writers. Carroll seems deliberate in making her students more informed consumers of the texts to which they are exposed. Horace, for example, is placed in the middle of a section entitled "Poets from 1688 to 1704," with Alexander Pope preceding him and Nicolas Boileau-Despréaux following. Alexander Pope, English poet and satirist, was also known as a translator of Homer. Pope credited part of his education to exposure to authors such as Horace. Nicolas Boileau-Despréaux, a French critic and poet, was best known for L'Art poétique and Le Lutrin, both of which imitate Horace's Ars Poetica. This would be a meaningless point of reference unless the student had had exposure to Horace. Thus, the inclusion of writers such as BoileauDespréaux necessitates the inclusion of classical authors and gives additional context to the education and works of authors such as Alexander Pope. This opportunity to expose her students to the classics also speaks to the depth of Carroll's personal literary education, which she then extends to her students.

Providing background information to her students allows them to be more informed consumers of popular fiction. The influence of the classics, as with women writers and popular novels, indicates that Carroll was aware, even though it is not explicitly stated, that her students were being exposed to such ideas in the texts they were consuming. Providing background information gives greater depth of knowledge, which 
then serves to validate their consumption by female readers. ${ }^{26}$ Essentially, it allows

Carroll's female students to be able to read and actively think about the texts they read, instead of being passive, uninformed receptors.

\section{Political Writers}

This trend continues in the way that Carroll introduces her students to political writers and thoughts. The curriculum includes a number of key political thinkers and philosophers, such as Rabelais (14), Swift $(14,29)$, Voltaire (14), Locke $(23,28)$, and Balzac (41). While Carroll often mentions authors' political careers or strong political alliances, these authors go beyond political positions to construct political philosophies. However, Carroll does not classify them with a focus on their politics; instead, she chooses to classify them as poets, essayists and satirists. John Locke, for example, is classified as a philosopher, but there is a noticeable lack of focus on his political ideas. Joseph Addison, whose play Cato is considered to have influenced early American political activists, is classified as an essayist; Jonathan Swift is also classified as an essayist. His works are covered extensively, even while she notes that his works ridiculed Catholics.

In a previously given example of female teachers sitting around discussing their various areas of interest, Carroll mentions their discussing politics (On Education, 6-7), so she sees politics as something women should converse on and that would be a source of pleasurable conversation. Moreover, the inclusion of these authors implies that Carroll believed female readers should be exposed to political writers and ideas. Despite these

\footnotetext{
${ }^{26}$ The reasoning behind this claim that Carroll was reading this type of material is that she mentions the literature in her diary, and the nature of women religious life would make it highly probable that the sisters were sharing the popular fiction that entered the community. Secondly, due to the school's being a boarding school, Carroll would be familiar with what her students were reading, since the environment of a boarding school removes the separation between private and public life.
} 
two assertions, Carroll still avoids creating a separate section for political writers and chooses to incorporate them into other genres. Exposing her students to these political theorists validates to her students that it is acceptable and expected that they be familiar with the art of satire, or reading essayists who question the political state. Their inclusion also serves to make Carroll's students more informed and aware of backgrounds that are steeped into popular fiction.

Current historiography no longer contends that women were entirely excluded from political influence, or that they were wholly apolitical. Robert E. May's article “Reconsidering Antebellum U.S. Women's History: Gender, Filibustering, and America's Quest for Empire," discusses how popular works of domestic fiction often alluded to and discussed filibustering. Likewise, Amy Kaplan explores the relationship of domesticity to nationalism and argues that mid-nineteenth-century domestic fiction revolves around thresholds such as doorways, which is predicated on the exploration of boundaries; she further argues that even women who were advocates for the separation of the domestic sphere from the male outside sphere, still read and wrote texts that were "subjectively scripted by narratives of nation and empire" (Kaplan Manifest 582; Kaplan Anarchy of Empire qtd. in May 1158). This leads Kaplan to contend that "domestic and foreign spaces are closer than we think" (qtd. in May 1158) and that women's domestic fiction advanced "political agendas," even if female authors conceived their role within the prescribed gender conventions (May 1157).

Despite the inclusion of political thinkers in her curriculum, however, Carroll did not advocate for women's suffrage, arguing that there was no reason for women to vote. Carroll warns her young instructresses that 
...in certain pedagogue writings, they commence by making amplifications on woman's rights on the emancipation of woman. Whither are we going? When an opportunity presents, prove the absurdity of all this to the young teacher and even to the pupil. Show them in true and smiling pictures the happiness of domestic life, always based on submission. Tell them also that you have never seen children obey a Mother who did not herself respect the wishes of her husband.

(On Education 29)

Barbara Matthews argues that in this era, being anti-suffrage was a quite common stance for advocates of female education. Citing Horace Mann, Henry Barnard, Emma Willard, and Catharine Beecher, Matthews notes that "both male and female educators were out of step with the broader women's movement... Both discouraged women from trying to secure suffrage, and both believed that women should not be equal to men in all professions... [but] education was essential for women" (50). Not only were key educators of the era anti-suffrage, so were some of the writers Carroll was promoting to her students. Authors like Catharine Sedgwick, who was previously discussed in the section on domestic writers, stated that "I cannot believe that it was ever intended that women should lead armies, harangue in the halls of legislature, bustle up to ballot-boxes, or sit on judicial tribunals" (Sedgwick 210; qtd. in Kelley "The Sentimentalist" 442). The reality of this era was that many writers and educators simply did not support suffrage.

This is not to say that Carroll chose to blindly encourage her students towards female subservience, but encouraged them to take stands in different areas. Carroll greatly admired Lady Mary Montagu, who is the first female writer in Carroll's curriculum, for being a writer "distinguished for her vivacity of intellect" (Literature 40). 
This writer was unhappily married, and Carroll describes her husband as a man whose "disposition was not at all suited to that of a gay lady of fashion" (40), which places the blame for the marital discord on the husband. Carroll then proceeds to note that despite her lack of marital bliss, Montagu portrayed "Admirable common sense, extensive reading and playful sarcasm tended to make her letters very popular. She has been compared to Madame de Sevigne, but possesses more intellectual caliber, though less refinement than the French writer" (40). Carroll portrays Montagu as a pioneer who had the bravery and foresight to have her child inoculated, despite the prejudices against vaccination, and commends her to her students because of her bravery and intellectual prowess. Later in her text, Carroll commends Madame de Maintenon for the same traits, describing her as a brave, heroic woman who overcame a tragic beginning to do much good.

Carroll's discussion of a female writer's marital discord points toward an interesting tension found throughout Carroll's texts. The tension is between the emphasis on the domestic, preparing pupils to become submissive wives and mothers, while having knowledge that marriage and motherhood could bring disaster and an inescapable unhappiness. Carroll's diary is filled with passages and quotations about educating virtuous and meek women, women who could take their proper place in the home, which are then accompanied by a personal reflection on a former student or friend who, she hopes, can find happiness in marriage. Yet Carroll admits to seeing the home as a restrictive place for women and has personally rejected the life of mother and wife for that of religious life, one of the few other acceptable options for respectable women who 
chose not to marry. ${ }^{27}$ Her text $O n$ Education discusses the personal satisfaction and freedom that arises from choosing an alternative lifestyle to the domestic. Yet in that text, Carroll vacillates between laying out a vision of female-centered, academically and personally fulfilling alternative domesticity, and then describing the joy felt by mothers tenderly caring for their children. Essentially, Carroll reiterates the rhetoric of the cult of motherhood for her young teachers and their pupils after admitting that there are other options. It is conceivable that Carroll was concerned about tempering some of her ideas, especially since the argument that there was not only an alternative to the societal domestic narrative surrounding the cult of motherhood, and that it could provide for greater intellectual joy, was dangerous. The anti-Catholic sentiment of the era was such that:

Male reformers denounced the vocation of the nun as a form of social deviance directly at odds with a woman's sacred roles of wife and mother ... [attacking] the celibacy of women religious as flouting the laws of God and Nature. The publisher's introduction to ...Scipio de Ricci's classic exposé Female Convents: Secrets of Nunneries Disclosed ... concluded that "nunneries and the conventual way of life, are altogether contradictory to the Divine appointments respecting the order of nature, and the constitutions of mankind and human society." (Mannard $308-10)$

The same era saw anti-convent petitions in the Maryland legislature (1856), which argued that nunneries were detrimental to the "positive welfare of society" because they "cut off so many from their social duty and a sphere of usefulness" (Mannard 310). As discussed

\footnotetext{
${ }^{27}$ Ironically, Carroll's students would later record how they would gossip about how someone so young and pretty would choose to be a Sister, instead of choosing marriage (Magill).
} 
previously, Carroll was writing in an era when the majority of the influential educators feared the Catholic Church and decried their convent schools, claiming that Sisters were too dangerous to educate Protestant children because they had rejected the traditional forms of domesticity - marriage, home, and motherhood (Mannard 309-11). For Carroll to suggest that not only should women be Sisters and teachers, but also that perhaps they could find greater joy in that life than in marriage, was very controversial and could have been seen as dangerous. However, it could also be that Carroll realistically understood what marriage entailed and the humility and submission that was expected from her pupils, the majority of whom would marry. In this case, Carroll is simply preparing them for what this role might entail.

This tension is not uncommon, and as Sicherman argues, "because of their subordinate position in society and their traditional consignment to the home, women more often than men have had to learn about life through books... on the one hand, girls were encouraged to develop their minds and even applauded for intellectual precocity. On the other, virtually everything they read and heard, whether emanating from press, pulpit, or academy, equated true womanhood with domesticity" (2). For Carroll, the books she chose to teach her students were much more than amusing texts used to pass time; the texts allowed her students to transcend the domestic and explore ideas that only males were encouraged to engage, while allowing her students this freedom in a way that did not clash with the sphere of the dominant male.

\section{Poetry}

Carroll continues her integration of female writers into her sections on poetry. Poetry was seen as key to the literary development of a student, and once again Carroll 
subtly introduces her students, not only to the power of female poets, but also to the fact that women could and did write poetry. Carroll herself was a writer of poetry, and her diary is filled with transcripts and clippings of poetry. Moreover, as mentioned previously, the recitation of poetry was a common part of a Nazareth girl's education. Within the American literature section of Carroll's text, the poetry section represents the largest subsection and is the last section of the book. Carroll reemphasizes the power of female writing with this section by titling an entire part "poetess." The female poets represented are "Mrs. Bradstreet, Mrs. Brooks, Mrs. Wilby, Mrs. Sigourney, Mrs. Oakes, Mrs. Embury, Mrs. Whitman, Mrs. Hewitt, Miss Lynch, Mrs. Osgood, Miss Sara Clark, Miss Gould, and the Davidsons (126)," with the implication that the Davidsons are a married couple whose writings "are instances of rare, though melancholy precocity in the art" (Literature 126). All of these women are placed together in her subsection marked "poetess" except Ann Bradstreet, who is listed with contemporary male poets.

With the section of poetry, Carroll makes an interesting deviation from the rest of her text. Normally, much of the criticism of an author is of her own composition, though it may be heavily informed or shaped by criticism that Carroll had read. As discussed previously, Carroll believed it was good to record the thoughts of others in her writing, as it made others' thoughts "in some sort our own" (diary 4). However, while she often notes who she is quoting, it can be difficult to tell in her curriculum what, if any, scholars she read to help develop her curriculum, as the material she presents is very consistent in style with her other texts, leading the reader to assume the curriculum is a compilation of her own ideas, while allowing that Carroll could be being informed by criticism she had 
previously read. The large amount of biographical information in the curriculum leads to the assumption that Carroll was likely referring to some literature critics or guides.

However, there is one instance where Carroll noticeably breaks form, and that is in the last entry in her curriculum about William Cullen Bryant. It begins with the following line: "the first thought which suggests itself in regards to Bryant, is his respect for the poetic act. To subserve [sic] the objects of the party, and to gratify personal ambition, the American poet is often tempted to sacrifice his true fame, and the dignity of Art to the demands of the occasion. This, Bryant has not done" (On Literature 126). Her personal description of his poetry is one of the most complimentary found in the entire text, saying that while many an American poet will "sacrifice his true fame, and the dignity of Art to the demands of the occasion. This, Bryant has not done" (126). Moreover, she is enthralled in his descriptions of nature, so much so that she breaks from her own criticism to quote Henry Theodore Tuckerman. Carroll quotes Tuckerman's observation that "Every moss covered trunk breathes to him of the mysteries of Time, and each wild flower which lifts its pale buds, above the brown and withered leaves, whispers some thought of gentleness" (Carroll126, Tuckerman 307). Carroll does not acknowledge that these words are not her own, but they are obviously very different from other entries in the text, making it easy to assume she is quoting someone else, despite that she does not use quotation marks. It's as if, for Carroll, her own words were not sufficient to praise this poet, and she draws on the poetic writings of others to greater described her feelings.

Carroll is more critical of the poets than she is of authors in any other genre, perhaps because of her love for poetry. For example, Carroll writes of the poet John Neal 
that he "has written some odes carelessly put together, but having memorable passages" (125). One of the key traits Carroll is looking for in regard to poets is command of language, one of the highest praises that she uses when describing a poet. Carroll expends little energy in acknowledging poets who do not engage her, though hints of her distaste for those she considers poor writers can be found in her commentary on prose writers, such as Bunyan, which will be discussed later in greater detail. At the same time, when a poet speaks to her as Bryant seems to do, her descriptions glow with admiration and warmth.

Carroll places a greater emphasis on poetry in the American literature section, which could be because of the enormous popularity of poetry at the time. But it could also be that Carroll finds American poets much less morally objectionable than European poets. In terms of European poets, there are entries such as that on James Thompson, where Carroll discusses how he was "greatly loved, and does not appear to have had a single enemy or ill-wisher" (62). Much more common, however, is commentary such as that on William Collins, who is described as having "ambition [that] was rather feverish than sustained - he led a life of projects and dissipation, and the first shock of literary disappointment drove him to despondency, despondency to indulgence, and indulgence to insanity" (62). As with her criticism of novels, Carroll dislikes poets whose characters she finds odious, noting in her commentary on Byron that he had "very little power in delineating variety of character, describing throughout his work only two kinds of dispositions, - one the voluptuous and selfish man, the other the weak, passionate, and devoted woman" (76) and, moreover, several of his works are "highly immoral, though replete with pathos" (76). She has the same distaste for overly sentimental poetry such as 
that by George Crabbe, whose "style is often very pathetic, and his pathos frequently reaches the extreme line of which sensibility will bear" $(70)$.

These objections being noted, Carroll also acknowledges that sometimes the improper or different is attractive to her students. When writing on the poet John Wolcott, who, Carroll finds, has a "coarse and pungent humor," she also notes that "his regular burlesque style makes his writing curious to the student, though their grossness excludes them from general readers" (72). This statement confirms the assumption that Carroll allows her students access to texts she finds objectionable. She asserts that, as they age, so will their taste improve, but the statement stands that she is comfortable in teaching writers who fall outside the standards of good taste.

\section{Religion}

In light of Carroll's focus on the moral, the question then becomes what role do religious texts play in her curriculum. Carroll is noted for devotion to her Church and her faith, and this influences her thoughts on educating women. Her diary is full of entries regarding religious texts and becoming a greater woman of God. Thus, it is of little surprise that one of her first sections in American literature is about religious writers. It should be noted that in the context of this thesis religious is used synonymously with Christian, as there are no non-Christian religious texts present in Carroll's curriculum. Carroll writes that she views American religious writing as "a natural consequence of emigration, induced by difference of religious opinion, and the variety of creeds represented by the different races who met on a common soil... The colonial era, therefore, boasted only [emphasis added] a theological literature" (103-4). In this early 
era, Carroll notes two theologians as being particularly influential: Jonathan Edwards and William Ellery Channing.

While Carroll does teach her students about Edwards and calls "Original Sin" his first "celebrity" (104) work, she is much more enthusiastic about Channing, whom she views as "achieving a world-wide reputation for genius in ethical literature" (104). Carroll's choice of religious writers is particularly interesting in that she chooses to focus on two non-Catholic theologians. Carroll includes theologians that her American students would be expected to know, since the authors were influential; however, she also carefully and subtly makes the point that "the diversity of sects is one of the most striking facts in our social history, and is illustrated by the literary organs of each denomination from the spiritual commentaries of Bush, to the ardent Catholicism of Brownson" (104). Carroll's preference for Channing is understandable because Unitarianism was much more accepting of Catholicism than Puritanism, but Carroll also includes Edwards, despite his anti-Catholic views.

The promotion of religious diversity accomplishes several significant things. Primarily, it fulfills the promise of the Sisters to not influence or change the religion of their Protestant students (Annual Catalogue of Nazareth Academy all years). Secondly, it gives the students a more well-rounded education and familiarity with early Protestant American writers, who are influential in many aspects of American life. This allows her students to be more active consumers of literature, as the influence of American religious writers can especially be found in the domestic writers that Carroll teaches. Thirdly, it supports the idea that America was a more religiously tolerant and accepting nation than its European counterparts. This sentiment is captured in an editorial that ran in the 
Catholic newspaper, Miscellany, which noted that, "In looking over our Southern Harmony communications from Europe, we have frequently to congratulate ourselves upon our state of religious freedom at this side of the Atlantic. . . The American people and the American government have done all they could or ought to do." (qtd. in Stern, 177-178).

Finally, scholars such as Andrew Stern argue that "to be sure, the antebellum South produced striking incidents of Catholic-Protestant animosity, and those incidents have loomed large in American religious historiography. Too large. More often than not, Protestants supported Catholics, particularly in building churches and schools" (165). This quotation acknowledges that the relationship between Protestants and Catholics in the South was not a clearly delineated animosity, but it does acknowledge that there was a chord of animosity and misunderstanding between Catholics and Protestants. The teaching of both Protestant and Catholic religious writers encourages theological tolerance and diversity as a historical characteristic of American culture. In an era fraught with anti-Catholic prejudices, the Know-Nothing movement had brought about massive demonstrations and destruction against Catholic neighborhoods and institutions, so encouragement of tolerance is an understandable goal. ${ }^{28}$

While American religious writers are grouped in their own genre, Carroll does not distinguish European religious writers with their own section. She integrates them into other groups, much along the lines of how she integrates the political writers previously discussed. For example, in her brief section of "Poets who lived between the time of Shakespeare and Milton," Carroll includes not just the dramatists and metaphysical poets,

\footnotetext{
${ }^{28}$ The Know-nothing movement violent demonstrations affected the Louisville area on August 6, 1855, a day referred to as "Bloody Monday." Louisville is 50 miles from Nazareth, and the SCNs had several missions in Louisville at this time.
} 
but also the theological writers of the English Civil War and the British Commonwealth. These writers include John Hales, William Chillingworth, Sir Thomas Browne, Thomas Fuller, Jeremy Taylor, and Richard Baxter; ${ }^{29}$ but Carroll also makes a point of including the Quaker writers Fox, Penn and Barclay (Literature 13). This makes her selection of religious writers fairly broad in regard to Christian denominations, since the list encompasses Anglicans, Puritans, Quakers, Calvinists, Catholics, and Quakers.

With the American religious writers, Carroll avoids offering criticism, but not so when writing about European religious writers. With these writers, Carroll uses the same language and critical lenses that she applies to other authors. One such example is John Bunyan (18-19), who, Carroll writes, " represents himself as extremely immoral, [though] a careful reading of his curious autobiography 'Grace abounding to the child of Sinners,' will convince the student that he only adopts the extravagant style of the Puritan" (18). Carroll takes care that her students do not form the impression that Bunyan once lived a life of debauchery, since as previously mentioned Carroll tends to not look favorably on writers who live scandalous lives. She also states that Bunyan was writing within the norm for Puritan literature, a style she finds "extravagant" (19). Yet, Carroll also seems unsure of what to do with Bunyan. She acknowledges that his work has been well-read and "learned and ignorant hang with rapture over its pages," (19) but her praise reads as controlled and limited. Her uneasiness regarding the text seems to hinge on the fact that she finds Bunyan an uneducated writer. She criticizes that he needed his friends

\footnotetext{
${ }^{29}$ John Hales was a Protestant who rejected Calvinism; Chillingworth was highly controversial in that he converted to Catholicism; Browne is likely the one with the most influence, being influential to the Romantics, Melville, and Poe. He was also a naturalist. Fuller and Taylor were Anglican clergy; Baxter was a Puritan, and as such, a Calvinist.
} 
to correct much of his work and that his lack of proficiency as a writer lessens the value of his text.

Though Carroll includes both European and American religious writers, as well as a representative sample of Christian denominations, overall the number of religious writers in the curriculum is rather narrow. This is especially noticeable since Carroll's diary indicates she was a prolific reader of religious texts, especially the works of Catholic writers. However, the lack of religious emphasis in Carroll's literary curriculum is not as unusual as might be expected. Carol Mattingly notes that

Literacy practiced in convent academies focused less on religion than in Protestant academies, which were not explicitly designated as denominational schools... In the Catholic convent academies, all students, including Protestants, attended religious services; however, because the Sisters relied upon income from the academies to maintain both the academy and the free schools for those less able to pay, they were careful not to dissuade wealthy Protestants from sending their daughter to convent academies. (174)

In this way, the literature curriculum at Nazareth Academy proved to be more open than some of the academies of equal note in the Northeast. Carroll saw herself as a woman of God and was seeking to show that to her pupils, but did not view it as her place to push a religious philosophy, leaving students free to make their own choices regarding faith.

Carroll does, however, tie religious writers to her other areas of interest, namely environmental interest. In her section on William Channing, who was one of Unitarianism's leading theologians as well as having significant influence on the New England Transcendentalists, Carroll leads into an introduction of natural theology. 
Natural theology was a popular theological notion in Carroll's era, and was an attempt to prove the existence of God and divine purpose through observation of nature and the use of human reason. Carroll links religion with a love of nature, saying in her diary that "man is indeed religious who beholds God in every created object, whose mind is exalted to him by every simplest phenomenon of Nature" (On Literature 243). Carroll believed in the power of environment to shape art and the author, and while this influence is less noticeable in her European section, it is interwoven throughout her American literature section. Carroll views Channing as someone who can't help but achieve beauty because he is one who is "baptized into the fraternity of Nature by the grandeur and beauty of the sea..."(105).

The ideas from transcendentalism and natural theology that emphasize the natural environment as a big, if not the biggest influence on a writer, are woven throughout the American literature section of the curriculum and her diary. Carroll is often meticulous about providing her students with a biographical description of a writer, then forming associations between the natural environment of the lives of her authors and the works they create. Charles Brockden Brown, for instance, was "an invalid from infancy, [who] had the dreamy woods and roaming propensity incident to poetical sympathies" (118). In essence, environment influences production and, indeed, the type of work produced by the author.

\section{Absent in the Curriculum}

After examining what is included in Carroll's text, it also is necessary to examine what is not in the text. Despite how advanced Carroll may have been in subtly promoting women writers and religious tolerance to her students, she also avoided certain 
controversial political topics. There are no books that touch on slavery or AfricanAmerican rights in her curriculum. ${ }^{30}$ The Sisters, as an organization, studiously avoided taking a side during the debate about slavery and the entire Civil War, operating as a neutral body and nursing both Confederate and Union troops. The lack of a firm stand may be attributed to two factors. First, Carroll could hardly risk teaching anti-slavery literature knowing that a huge portion of her student population would have pro-South sentiments. Nazareth Academy did not have the benefits of her northern cousins in being safely confined in a firmly anti-slavery geographical area. Nazareth Academy was located in a divided state and was educating the daughters of both the North and the South. Carroll could not afford to alienate either. Secondly, it could be that Carroll, and the SCNs in general, did not believe that it was their place as women religious to push any overt political message. Carroll chose literature to subtly promote women and the ideas of natural theology, while the issue of slavery was much more overtly political; the Sisters did not feel it was their place to engage in the political realm, especially in light that the Catholic Church did not have an anti-slavery position during this era.

While the lack of pro- or anti-slavery narratives is understandable in light of the political era, there is a tension regarding class in Carroll's literature curriculum choices. The religious texts in her curriculum espouse the necessity of charity and caring for the poor, and Carroll notes in her On Education her concern about preparing students for the economic instability they may encounter. This stated, Carroll does not seek to enlighten her pupils by having them read texts about the poor. That is not to say there is no poverty in the texts that Carroll teaches, but it is the genteel poverty as typified in Austen or

\footnotetext{
${ }^{30}$ Several of the female domestic writers previously mentioned also wrote anti-slavery texts. Carroll does not list their antislavery texts among their works.
} 
Thackeray. The poverty that Carroll exposes her students to is not the immigrant or street child poverty of Dickens. In fact, Charles Dickens is not found anywhere within Carroll's curriculum, even though she mentions her admiration for the writer in her diary, and he was by far one of the most popular writers of the era.

The lack of attention to the poor in Carroll's curriculum is of particular interest since economic instability is a key point of Carroll's text on pedagogy. She encourages her pupils to learn the difference between basing their self-worth on outside factors such as wealth, status, or even their talents, and instead learn to base their self-worth on personal merits, such as kindness, friendship, and patience, which Carroll believes can never be taken from them. Carroll warns that young women will often fantasize about their lives, dreaming of nobility, great marriages and even greater fortunes that come with husbands; Carroll encourages her instructresses to dash those irrational dreams but to do it with gentleness. For Carroll, young women don't understand money or the ways in which the markets work, which was problematic with the economic instability of the era. This was a concern for Carroll since her students' lives could be full of changes in personal fortune, especially as women often had little influence or power in the finances of the home (On Education 49-50).

Carroll particularly worries about students she calls "sleeping beauties." These are students who live in the world of fantasies, which leads them to unrealized expectations. She notes that this is most often a trait in upper-class scholars who are critical of learning useful skills such as sewing and managing household tasks. Carroll argues these will be useful skills for charity, days of boredom, and days of needs, trials, and exiles (92). It is possible that Carroll believes that the genteel poverty she exposes her students to in 
writers like Austen is more like the poverty her students may face than abject poverty. However, it could easily be argued that Carroll did not see the value of including texts about the truly poor, either because they are too controversial, or of general disinterest.

The concern that her students were living in a fantasy world is one that Carroll shared with other educators in female academies. However, while some of Carroll's contemporaries would argue that these fantasies stem from reading fiction, Carroll obviously disagrees, since she teaches fiction. Central to Carroll's curriculum is her belief in the power of literature to be a positive influence on the lives of her students, which is evident throughout her personal writings and her literature curriculum. Carroll uses her influence to encourage her pupils to see their sex as capable writers, while acknowledging that their world would likely be limited. She encourages them to find freedom and themselves in the literature that they read, yet as with the case of political literature, Carroll didn't have or didn't feel as if she had the power to overcome the political and social realities of the world she lived in. However, she did see that literature could be a catalyst to explore and more fully understand the world.

This attitude was likely evident to her students. Historians have noted that the generation of women raised between the 1850 s and the 1870 s was heavily influenced by literature, and this era saw a rise in women's reading and the utilization of reading as a social tool. They were entering the world as authors, engaging with the political realm, and using literature as a catalyst in establishing their place in their country (see Sicherman). These ideas were subtly reinforced by female academies, and by the influence of teachers such as Carroll, who helped young women encounter new ideas that would blossom into independence. 


\section{CONCLUSION}

Columba Carroll's SCN mission was simple. She was to guide her young female students and the Sister-teachers under her in becoming more intelligent, affable women. The students were to be taught the skills and talents necessary to become loyal wives and good Christian mothers; the Sisters were to be trained in the skills necessary to teach said young women. Her legacy has largely been forgotten outside of the SCN Community, but the reality of Carroll's accomplishments has far greater implications, not only for her students and the young educators, but also for our understanding of female education.

The case study of Nazareth Academy and Carroll is ideal in several ways. First of all, while this study is limited because of its focus on a specific academy, the longevity and esteemed reputation of Nazareth Academy serves to make it a valuable source for investigation. It was a southern school and a Catholic institution, which allows us to begin filling in the gaps in the research of female academies. The goal was to examine the context in which Carroll was writing by critically looking at Nazareth Academy's history and significance, which allows for a better understanding of the role of the institution and places it within trends in female education. But this study also sought to look past the institution and give voice to the experience of the teachers and students. Within the walls of this academy, hundreds of young students received an education, formed deep friendships, and grew into women. These students were educated by female teachers wholly invested in a mission of education. 
One of the ways to give voice to these students and to Carroll was to critically examine her views and educational method, while placing her pedagogy and curriculum in the educational context of the era. Carroll's forty years as an educator and administrator deeply impacted her institution and the students that she taught. Indeed, Carroll's diary even records that her legacy spanned generations, as she notes teaching the daughters of her former students (Letter to Julia Stone 1858). While there is no way to definitively say how long after Carroll's death her curriculum was used in the academy, her influence and the literature she introduced would have impacted her students long after they left her guidance. However, her legacy would also be carried on by the young Sisters who were educated as teachers under her influence.

Carroll's literature curriculum reveals that female students were actively reading and encouraged to think about fiction, women writers, and poetry. Carroll worked to help her students become more informed consumers of literature by giving them a background in classics, politics, and religion. Carroll's willingness to present information to her students and allow them to make decisions for themselves regarding authors and texts was a sign of the faith she had in her students. But it is also a work in reclaiming the literary texts used in the academy and their role in literary history. Carroll's curriculum proves that, within this academy, works by female writers such Ann Radcliffe, Lady Montagu, and Maria Edgeworth were taught in the classroom. This knowledge allows us to more fully understand how these texts were being utilized by female readers, which gives new dimension outside of private consumption.

Academic investigation into works such as Carroll's literature curriculum and her text on pedagogy works to expand our perceptions of female education and academies. It 
is a glimpse past the assumption that students in female academies might have been reading a range of texts from religious to popular novels, and gives definitive evidence of what texts Carroll's students were being exposed to. Moreover, Carroll's personal correspondence and diaries give us a more intimate look into the thoughts of this female educator. The written legacy Carroll left allows for an investigation of a woman who was thinking critically about education, and then implementing her ideas in a very tangible way through her writings on pedagogy and literature.

Part of what made Carroll such an informed teacher was that she was a passionate and prolific reader, who greatly valued the power of the written word. In a letter to a former student, Carroll writes, "what a delight it is to be able to appreciate and enjoy the works of the gifted and the holy! With an interesting book, one can forget many petty cares and annoyances" (Carroll to Eliza Cook 1855). Carroll saw literature as a way to transcend the troubles of daily life, which is significant for a woman who struggled with the limitations of the domestic. Literature was a way her students could interact with the world in ways that were otherwise limited to them because of their gender. As Mary Kelley notes "nowhere is the fruit of their [women's] collective practice more apparent than in their use of reading to mediate between the gender conventions of their century and the new ideal they were creating, that of the learned woman" ("Making of a Learned Woman 55). This mediation is seen throughout Carroll's text, as she was not only a "learned" woman, but one who dedicated her entire life to educating future generations of women, yet was bound by societal conventions on women.

However, as with the nature of this type of archival investigation, there is always a need for more research. While the evidence presented in this thesis is generally 
unknown in academia, it is grounded in the research of other scholars who share in exploring the history of female education and women's readership. Carroll's educational texts have safely been ensconced in the Sisters of Charity of Nazareth Archives awaiting the time when they would serve those interested in education. The joys and the frustrations of archival research lie in the unknown. I assume, and deeply hope, that other treasures such as Carroll's texts, letters, and diary will be uncovered in other archives, and will continue to add to our understanding and appreciation for the extraordinary educational legacy of women and for women. 


\section{REFERENCES}

Baym, Nina. Woman's Fiction: A Guide to Novels by and about Women in America, 1820-70. Urbana-Champaign: University of Illinois Press, 1993. Print.

Beadie, Nancy. "Academy Students in the Mid-Nineteenth Century: Social Geography, Demography, and the Culture of Academy Attendance" History of Education Quarterly 41.2 (Summer, 2001): 251-262. Jstor. Web.

---. "Female Students and Denominational Affiliations: Sources of Success and Variations among Nineteenth-Century Academies." American Journal of Education 107.2 (Feb. 1999): 75-115. Jstor. Web.

Carroll, Columba, SCN. Course of Literary Study. Unpublished Manuscript. Sisters of Charity of Nazareth Archival Center. Print.

---. Diary. Unpublished manuscript. Sisters of Charity of Nazareth Archival Center. Print.

---. Letter to Dr. F.R. Alpuente, 1855. Collected Letters of Mother Columba Carroll, V. I. Unpublished manuscript. Sisters of Charity of Nazareth Archival Center. Print.

---. Letter to Eliza Cook, 22 Jan. 1855. Collected Letters of Mother Columba Carroll, V. I. Unpublished manuscript. Sisters of Charity of Nazareth Archival Center. Print.

---. Letter to Mother Frances Gardiner, 2 Feb. 1854. Collected Letters of Mother Columba Carroll, V. I. Unpublished manuscript. Sisters of Charity of Nazareth Archival Center. Print.

---. Letter to Julia Stone, 13 Nov. 1858. Collected Letters of Mother Columba Carroll, V. I. Unpublished manuscript. Sisters of Charity of Nazareth Archival Center. Print. 
---. On Education in Boarding-schools for Young Ladies, Book 1. Unpublished manuscript. Sisters of Charity of Nazareth Archival Center. Print.

---. Sister Permanent Record Card, Sisters of Charity of Nazareth Archival Center. Print. Cook, Blanche Weisen. "Female Support Networks and Political Activism: Lillian Wald, Chrystal Eastman, Emma Goldman." Chrysalis 3 (1977): 43-61. Print.

Corcoran, Miriam, SCN. A Survey of the Educational Ministry of the Sisters of Charity of Nazareth. Nazareth, KY: SCN Internal Publication, 1996. Sisters of Charity of Nazareth Archival Center. Print.

Cott, Nancy F. The Bonds of Womanhood: "Woman's Sphere" in New England, 17801835. New Haven: Yale University Press, 1997. Print.

Degler, Carl. At Odds: Women and the Family in America from the Revolution to the Present. USA: Oxford University Press, 1981. Print.

Edward, June. Women in American Education, 1820-1955: The Female Force and Educational Reform. Westport, Conn: Greenwood Press, 2002. Print.

Farnham, Cristie Anne. The Education of the Southern Belle: Higher Education and Student Socialization in the Antebellum South. New York: New York University Press, 1994. Print.

Greenwell, Bernice, SCN. Nazareth's Contribution to Education, 1812-1933. Diss. Fordham University, 1933. New York. Print. Graff, Harvey. The Literacy Myth: Cultural Integration and Social Structure in the Nineteenth Century. New Brunswick, NJ: Rutgers University Press, 1994. Print. 
Griffin, Susan M. "Reading American Women." Cambridge History of American Women's Literature. Ed. Dale Bauer. Cambridge: Cambridge UP, 2012. Manuscript copy provided by author.

Kaplan, Amy. "Manifest Domesticity." No More Separate Spheres!. Spec. issue of American Literature,70.3 (Sep.1998): 581-606. Jstor. Web.

---. The Anarchy of Empire in the Making of U.S. Culture. Cambridge, Mass.: Harvard University Press, 2002. Print.

Kelley, Mary. Learning to Stand and Speak: Women, Education, and Public Life in America's Republic. Chapel Hill: University of North Carolina Press, 2006. Print.

---. "The Making of Learned Women in Antebellum America." Reading Acts: U.S. Readers' Interactions with Literature, 1800 - 1950. Eds. Barbara Ryan and Amy M. Thomas. Knoxville: The University of Tennessee Press, 2002. 53 - 78. Print.

--- "The Sentimentalists: Promise and Betrayal in the Home." Signs, 4.3 (Spring, 1979): 434-446. Jstor. Web.

Kerber, Linda. "Separate Spheres, Female Worlds, Woman's Place: The Rhetoric of Women's History." The Journal of American History, 75.1 (Jun.1988): 9-39. Jstor. Web.

Kleinberg, S.J. Women in the United States, 1830 -1945. New Brunswick, NJ: Rutgers University Press. 1999. Print.

Kraditor, Aileen S., ed. Up from the Pedestal: Selected Writings in the History of American Feminism. Chicago: Quadrangle Books , 1968. Print.

Krumpelman, Frances, SCN. Mothers Superior, Mothers General 1813-1972. Sisters of Charity of Nazareth. 31 May 2002. Internal Publication. 
Kathryn Kish Sklar, Catharine Beecher: A Study in American Domesticity. New Haven: Yale University Press, 1973. Print.

Leslie, Bruce. "Where Have all the Academies Gone?" History of Education Quarterly 41 (2001): 262-70. Jstor. Web.

Lewis, Alvin Fayette. United States Bureau of Education Circular of Information: History of Higher Education in Kentucky. Washington: Government Printing Office, 1899. Rare Book Collection. Sisters of Charity of Nazareth Archival Center. Print.

Mannard, Joseph G. "Maternity... of the Spirit. Nuns and Domesticity in Antebellum America." Women in the Catholic Community. Spec. issue of U.S. Catholic Historian 5.3/4 (Summer-Fall 1986): 305-324. Jstor. Web.

Matthews, Barbara. "Women, Education and History." Democracy in Education. Spec. Edition of Theory into Practice 15.1 (February 1976). Jstor. Web.

Mattingly, Carol. "Uncovering Forgotten Habits: Anti-Catholic Rhetoric and NineteenthCentury American Women's Literacy." College Composition and Communication 58.2 (December 2006): 160-181. Jstor. Web.

May, Robert E. “Reconsidering Antebellum U.S. Women's History: Gender, Filibustering, and America's Quest for Empire." American Quarterly 57.4 (Dec., 2005): 1155-1188. Jstor. Web.

McGann, Agnes Geraldine, SCN. Interesting Facts about Education At Nazareth. SCN Internal Publication: Nazareth, KY. Sisters of Charity of Nazareth Archival Center. 1994. Print. 
---. Mother Columba Carroll: Sister of Charity of Nazareth, 1810-1878. SCN Internal

Publication: Nazareth, KY.. Sisters of Charity of Nazareth Archival Center. February 1973. Print.

McGill, Anna Blanche. The Sisters of Charity of Nazareth, Kentucky. New York: The Encyclopedia Press, 1917. Rare Book Collection. Sisters of Charity of Nazareth Archival Center. Print.

Menard, Marie, SCN. Clippings for Annals. Clippings Collection. Sisters of Charity of Nazareth Archival Center. Print.

More, Hannah. Coelebs in Search of a Wife: Domestic Habits and Manners, Religion and Morals. Vol 1-2. London: T. Cadell and W. Davies, 1808. Web. Google Books.

Mother Columba Carroll, undated: Sisters' Picture Book 3, Photograph/Image Collection, Sisters of Charity of Nazareth Archival Center

Mother Columba Carroll, undated: Sisters' Picture Book 3, Photograph/Image Collection, Sisters of Charity of Nazareth Archival Center

Nazareth Academy, circa 1830s-1850. Nazareth Box B: Nazareth Academy, Photograph/Image Collection, Sisters of Charity of Nazareth Archival Center. Print.

Nazareth Academy, 1871. Nazareth Box B: Nazareth Academy, Photograph/Image Collection, Sisters of Charity of Nazareth Archival Center. Print.

Nazareth Academy Annual Catalogue, 1857 - 1858. Nazareth Academy Collection,

Sisters of Charity of Nazareth Archival Center. Print.

Nazareth Academy Annual Catalogue, 1858 - 1859. Nazareth Academy Collection, Sisters of Charity of Nazareth Archival Center. Print. 
Nazareth Academy Annual Catalogue, 1859 - 1860. Nazareth Academy Collection, Sisters of Charity of Nazareth Archival Center. Print.

Nazareth Academy Annual Catalogue, 1860 - 1861. Nazareth Academy Collection, Sisters of Charity of Nazareth Archival Center. Print.

Nazareth Academy Annual Catalogue, 1864 - 1865. Nazareth Academy Collection, Sisters of Charity of Nazareth Archival Center. Print.

Nazareth Academy Annual Catalogue, 1865 - 1866. Nazareth Academy Collection, Sisters of Charity of Nazareth Archival Center. Print.

Nazareth Academy Annual Catalogue, 1866 - 1867. Nazareth Academy Collection, Sisters of Charity of Nazareth Archival Center. Print.

Nazareth Academy Annual Catalogue, 1867 - 1868. Nazareth Academy Collection, Sisters of Charity of Nazareth Archival Center. Print.

Nazareth Academy Annual Catalogue, 1869 - 1870. Nazareth Academy Collection, Sisters of Charity of Nazareth Archival Center. Print.

Nazareth Academy Annual Catalogue, 1870 - 1871. Nazareth Academy Collection, Sisters of Charity of Nazareth Archival Center. Print.

Norton, Mary Beth, Ruth M. Alexander, and Thomas Paterson. Major Problems in American Women's History. Boston: Houghton Mifflin, 2006. Print.

Preston, Jo Anne. "Domestic Ideology, School Reformers, and Female Teachers: Schoolteaching Becomes Women'sWork in Nineteenth-Century New England." The New England Quarterly 66.4 (Dec., 1993): 531-551. Jstor. Web.

"Scollay, Mary". Nazareth Academy Student Records, Sisters of Charity of Nazareth Archival Center. Print. 
Sedgwick, Catharine Maria. Means and Ends, or Self-Training. Boston: Marsh, Capen, Lyon, and Webb, 1839. Web. Google books.

Sicherman, Barbara. Well-Read Lives. Chapel Hill: University of North Carolina Press, 2010. Print.

Smith-Rosenberg, Carroll. "The Female World of Love and Ritual: Relations between Women in Nineteenth-Century America." Signs 1(Autumn 1975): 1 -29. Print.

Stern, Andrew. "Southern Harmony: Catholic-Protestant Relations in the Antebellum South" Religion and American Culture: A Journal of Interpretation 17. 2 (Summer 2007): 165-190. Jstor. Web.

Sweet, Leonard I. "The Female Seminary Movement and Women's Mission in Antebellum America." Church History 54.1 (March 1985): 41-55. Jstor. Web. Thebaud, Augustus J. Forty Years in the United States, 1837 - 1885. New York: The United States Catholic Historical Society, 1904. Web. Google Books.

Tolley, Kim. "Science for the Ladies, Classics for Gentlemen: A Comparative Analysis of Scientific Subjects in the Curricula for Boys' and Girls' Secondary Schools in the United States, 1794-1850." History of Education Quarterly. 36.2 (Summer 1996): 129-135. Jstor. Web.

--- "The Rise of the Academies: Continuity or Change?" History of Education Quarterly 41.2 (Summer 2001): 225-239. Jstor. Web. 
Tuckerman, Henry Theodore. Thoughts on the Poets. C.S. Francis and Co.: Boston, 1848. Web. Google Books.

Wayne, Tiffany K. Women's Roles in Nineteenth-Century America. Westport, Conn: Greenwood Press, 2007. Print.

Welter, Barbara. "The Cult of True Womanhood: 1820 - 1860." American Quarterly 18 (Summer 1966): 151 - 174. Jstor. Web. 


\section{Image 1}

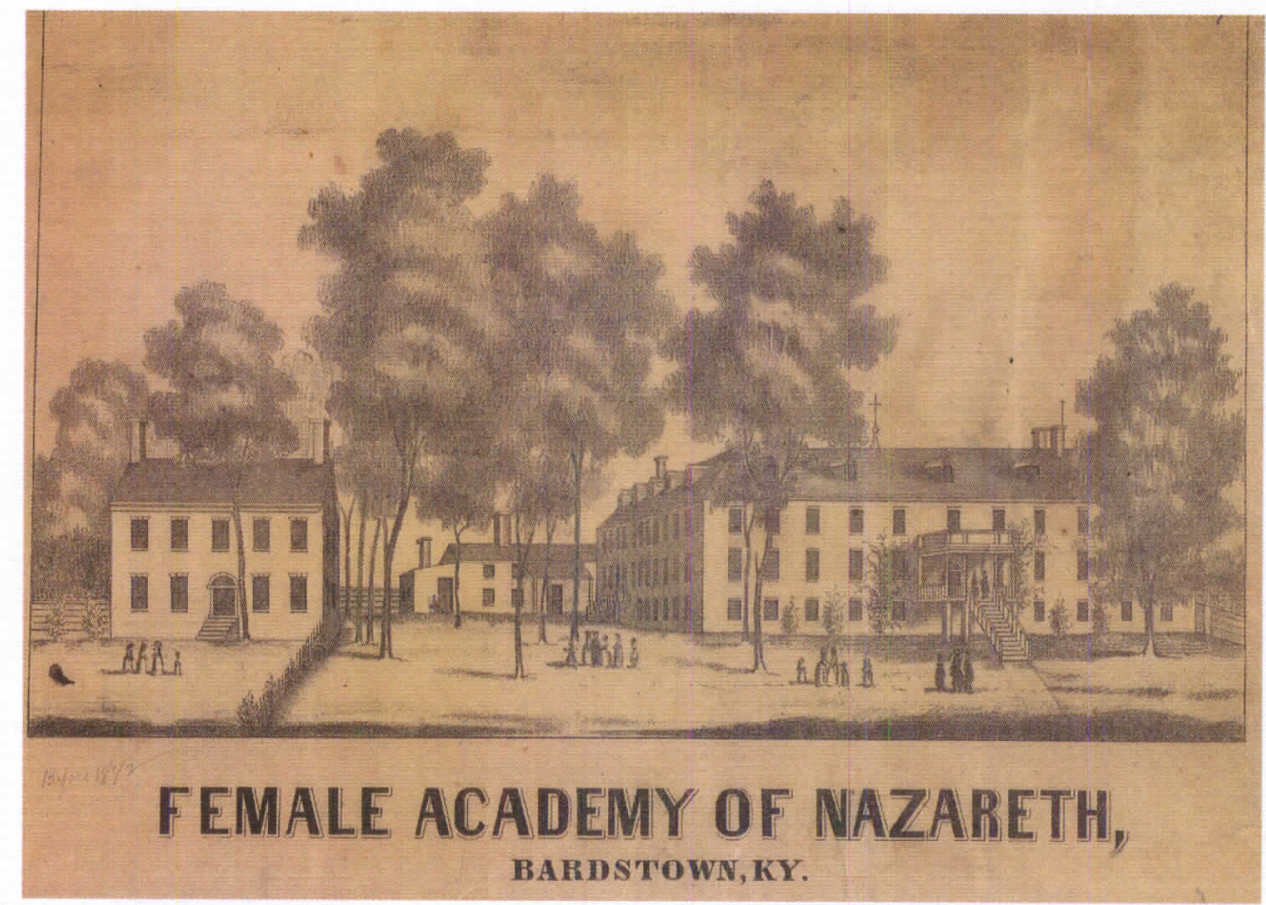

Nazareth Academy, circa 1830s-1850, Nazareth Box B: Nazareth Academy, Photograph/Image Collection, Sisters of Charity of Nazareth Archival Center

\section{Image 2}

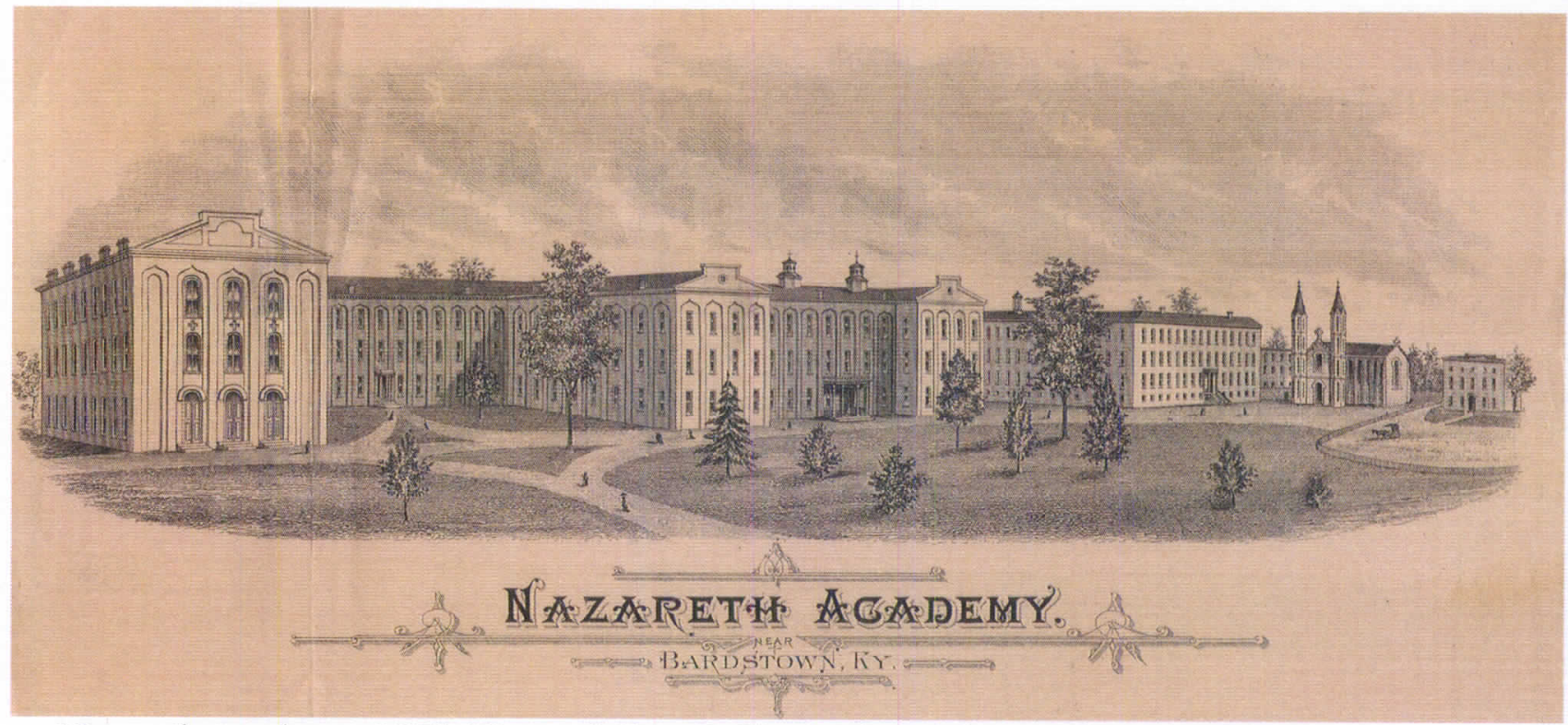

Nazareth Academy, 1871, Nazareth Box B: Nazareth Academy, Photograph/Image Collection, Sisters of Charity of Nazareth Archival Center 


\section{Image 3}

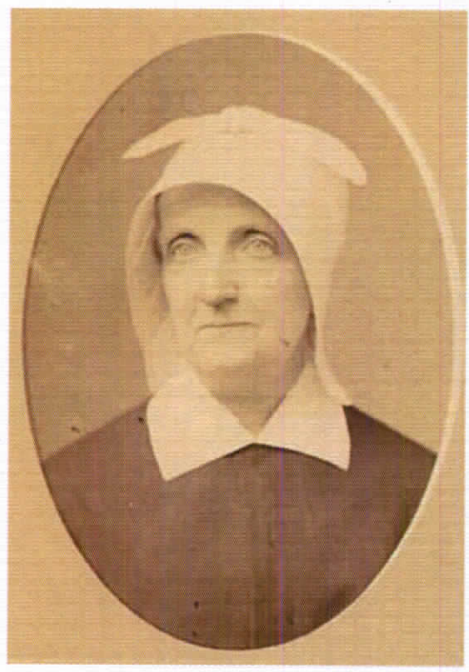

Mother Columba Carroll, undated: Sisters' Picture Book 3, Photograph/Image Collection, Sisters of Charity of Nazareth Archival Center

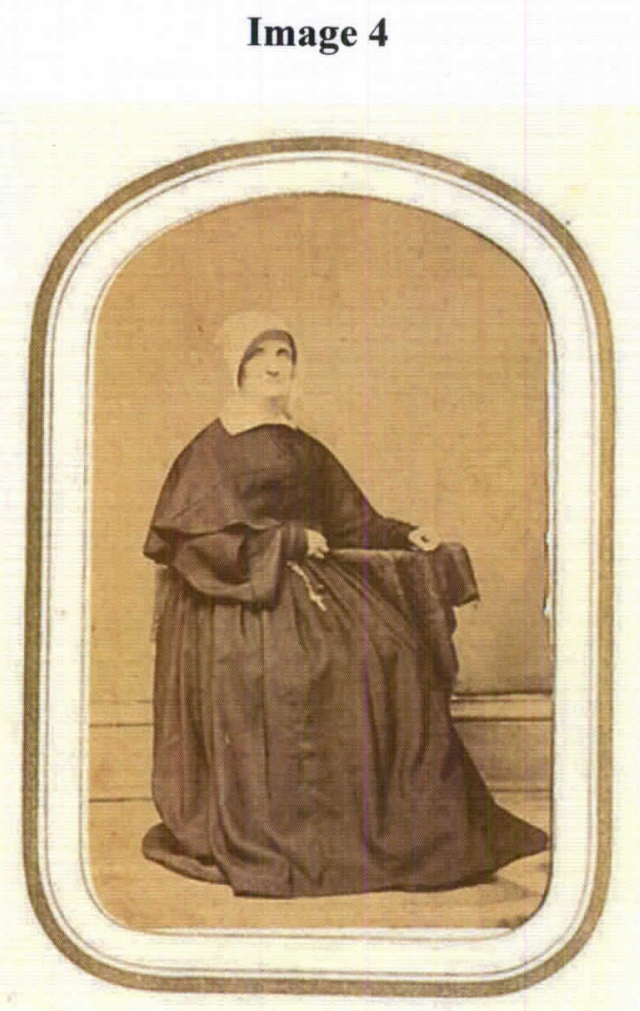

Mother Columba Carroll, undated: Sisters' Picture Book 3, Photograph/Image Collection, Sisters of Charity of Nazareth Archival Center 
Table 1: Estimated Enrollment figures for SCN Academies, 1865 - 1880

\begin{tabular}{|c|c|c|c|c|}
\hline Academy Name, Location, and Dates & 1865 & 1870 & 1875 & 1880 \\
\hline $\begin{array}{l}\text { Nazareth Academy, Nazareth, KY } \\
\quad 1814-1966\end{array}$ & 235 & 314 & 229 & 109 \\
\hline $\begin{array}{l}\text { Bethlehem Academy, Bardstown, KY } \\
1819 \text { - ongoing }\end{array}$ & 60 & $\mathrm{n} / \mathrm{a}$ & 60 & 80 \\
\hline $\begin{array}{l}\text { St Vincent's Academy, Union County, KY } \\
1820-1967\end{array}$ & 100 & $\mathrm{n} / \mathbf{a}$ & 100 & 60 \\
\hline $\begin{array}{l}\text { Presentation Academy, Louisville, KY } \\
1831 \text { - ongoing }\end{array}$ & 100 & $\mathrm{n} / \mathbf{a}$ & 70 & 70 \\
\hline $\begin{array}{l}\text { St. Catherine Academy, Lexington, KY } \\
1833-1951\end{array}$ & 100 & $\mathrm{n} / \mathrm{a}$ & 100 & 100 \\
\hline $\begin{array}{l}\text { St. Frances Academy, Owensboro, KY } \\
1849-1951\end{array}$ & 75 & $\mathrm{n} / \mathbf{a}$ & 130 & 130 \\
\hline $\begin{array}{l}\text { LaSalette Academy, Covington, KY } \\
\quad 1856-1977\end{array}$ & $\mathrm{n} / \mathrm{a}$ & $\mathrm{n} / \mathbf{a}$ & $\mathrm{n} / \mathrm{a}$ & $\mathrm{n} / \mathrm{a}$ \\
\hline $\begin{array}{l}\text { Immaculata Academy, Newport, KY } \\
1857-1932\end{array}$ & $\mathrm{n} / \mathrm{a}$ & $\mathrm{n} / \mathrm{a}$ & $\mathrm{n} / \mathrm{a}$ & $\mathrm{n} / \mathrm{a}$ \\
\hline $\begin{array}{l}\text { St. Mary Academy, Paducah, KY } \\
1858-1965\end{array}$ & 150 & $\mathrm{n} / \mathrm{a}$ & 70 & 70 \\
\hline $\begin{array}{l}\text { St. Columba Academy, Bowling Green, KY } \\
1863-1912\end{array}$ & $\mathrm{n} / \mathrm{a}$ & $\mathrm{n} / \mathbf{a}$ & 130 & 130 \\
\hline $\begin{array}{l}\text { Bethlehem Academy, Holly Springs, MS } \\
1868-1875\end{array}$ & & $\mathrm{n} / \mathbf{a}$ & $\mathrm{n} / \mathrm{a}$ & 37 \\
\hline $\begin{array}{l}\text { St. Joseph's Academy, Frankfort, KY } \\
1870-1917\end{array}$ & & $\mathrm{n} / \mathrm{a}$ & $\mathrm{n} / \mathrm{a}$ & $\mathrm{n} / \mathrm{a}$ \\
\hline $\begin{array}{l}\text { St. Theresa's Academy, Rhodelia, KY } \\
1870-1926\end{array}$ & 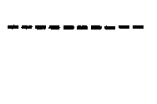 & $\mathrm{n} / \mathbf{a}$ & 40 & 40 \\
\hline $\begin{array}{l}\text { St. Clara Academy, Yazoo City, MS } \\
1872-1942\end{array}$ & -- & ---- & 68 & 60 \\
\hline
\end{tabular}

Sources: All information comes from the Catholic Almanac, except the enrollment statistics for Nazareth Academy, which are located in the Nazareth Academy Annual Catalogue. The accuracy of the Catholic Almanac is debatable, especially noting how often the enrollment numbers do not change. However, it offers an estimate for enrollment. Enrollment numbers are normally not listed for the Diocese of Covington, with the exception of St. Catherine's Academy. Additionally, there was no enrollment information listed in the 1870 Catholic Almanac, nor the 1869 and 1871 editions. 
Table 2: Nazareth Academy Student Demographics by Home State, 1857 - 1870

$\begin{array}{cc}\mathbf{1 8 5 7} \text {-1858 } & \\ \text { Kentucky } & 74 \\ \text { Louisiana } & 67 \\ \text { Mississippi } & 51 \\ \text { Tennessee } & 7 \\ \text { Indiana } & \mathbf{8} \\ \text { Ohio } & 3 \\ \text { Texas } & 2 \\ \text { Missouri } & 2 \\ \text { Arkansas } & 1 \\ \text { Illinois } & 1 \\ \text { Alabama } & 1\end{array}$

Total 202

$\begin{array}{ll}\mathbf{1 8 6 0} \text { - 1861 } & \\ \text { Louisiana } & 95 \\ \text { Kentucky } & 61 \\ \text { Mississippi } & 38 \\ \text { Alabama } & 11 \\ \text { Indiana } & 8 \\ \text { Texas } & 8 \\ \text { Missouri } & 7 \\ \text { Tennessee } & 5 \\ \text { Illinois } & 3 \\ \text { Ohio } & 3 \\ \text { Arkansas } & 2 \\ \text { Mexico } & 1\end{array}$

$\begin{array}{ll}\mathbf{1 8 5 8} \text { - 1859 } & \\ \text { Louisiana } & \mathbf{8 8} \\ \text { Kentucky } & 76 \\ \text { Mississippi } & 52 \\ \text { Tennessee } & 8 \\ \text { Indiana } & 5 \\ \text { Missouri } & 4 \\ \text { Ohio } & 3 \\ \text { Illinois } & 2 \\ \text { Alabama } & 2 \\ \text { Arkansas } & 1 \\ \text { Mexico } & 1\end{array}$

Total 242

$\begin{array}{ll}1864 \text { - 1865 } & \\ \text { Kentucky } & 190 \\ \text { Tennessee } & 65 \\ \text { Mississippi } & 20 \\ \text { Louisiana } & 14 \\ \text { Missouri } & 10 \\ \text { Arkansas } & 5 \\ \text { Indiana } & 3 \\ \text { Alabama } & 3 \\ \text { Ohio } & 2 \\ \text { Texas } & 2 \\ \text { D.C. } & 1 \\ \text { Mexico } & 1\end{array}$

$\begin{array}{ll}\mathbf{1 8 5 9} \text { - 1860 } & \\ \text { Louisiana } & 100 \\ \text { Kentucky } & 55 \\ \text { Mississippi } & 55 \\ \text { Indiana } & 9 \\ \text { Tennessee } & \mathbf{8} \\ \text { Alabama } & 7 \\ \text { Missouri } & 6 \\ \text { Arkansas } & 4 \\ \text { Ohio } & 4 \\ \text { Texas } & 4 \\ \text { Illinois } & 2 \\ \text { Florida } & 1 \\ \text { New York } & 1 \\ \text { Mexico } & 1\end{array}$

Total 316

No data available for $1861 / 62$ 1863/64 School Years

Total 235 
1865 - 1866

Kentucky $\quad 156$

Tennessee $\quad 76$

Mississippi 73

Louisiana $\quad 15$

Arkansas 13

Indiana $\quad 10$

Illinois $\quad 8$

Alabama 5

Ohio 4

Texas 3

Missouri 2

Georgia 2

Canada 1

Mexico 1

Total 369

\section{$1867-1868$}

Kentucky $\quad 110$

Mississippi 96

Tennessee $\quad 34$

Louisiana 29

Arkansas 9

Alabama 9

Indiana 7

Missouri 7

Pennsylvania 2

Illinois 2

Georgia 2

Florida 2

Texas 1

Total 310
1868 - 1869

Kentucky $\quad 115$

Mississippi 100

Tennessee $\quad 38$

Louisiana 35

Alabama $\quad 15$

Arkansas 11

Missouri 5

Florida 5

Indiana 4

Illinois 2

Ohio 2

Georgia 2

Montana 2

Pennsylvania 2

Texas 1

Total 339

$\begin{array}{ll}1869 \text { - 1870 } & \\ \text { Kentucky } & 93 \\ \text { Mississippi } & 85 \\ \text { Tennessee } & 37 \\ \text { Louisiana } & 35 \\ \text { Alabama } & 16 \\ \text { Arkansas } & 13 \\ \text { Georgia } & 10 \\ \text { Florida } & 8 \\ \text { Illinois } & 5 \\ \text { Indiana } & 4 \\ \text { Missouri } & 3 \\ \text { Minnesota } & 2 \\ \text { Ohio } & 1 \\ \text { Texas } & 1 \\ \text { Pennsylvania } & 1\end{array}$

Total 314 
Table 3: Expansion of Curriculum of Nazareth Academy, Nazareth, KY, 1826-1870

\begin{tabular}{|c|c|c|c|}
\hline 1826 & 1833 & 1858 & 1870 \\
\hline $\begin{array}{l}\text { Reading } \\
\text { Writing } \\
\text { Arithmetic } \\
\text { Grammar } \\
\text { Composition } \\
\text { History \& } \\
\text { geography } \\
\\
\text { Logic } \\
\text { Rhetoric } \\
\text { Natural } \\
\text { philosophy } \\
\text { Plain sewing } \\
\text { Ornamental } \\
\text { needlework } \\
\text { Embroidery } \\
\text { Tapestry } \\
\text { Drawing } \\
\text { Painting } \\
\text { Music } \\
\text { Politeness } \\
\text { French }\end{array}$ & $\begin{array}{l}\text { Reading } \\
\text { Writing } \\
\text { Arithmetic } \\
\text { Grammar } \\
\text { Composition } \\
\text { History \& } \\
\text { geography } \\
\\
\text { Logic } \\
\text { Rhetoric } \\
\text { Natural \& moral } \\
\text { philosophy } \\
\text { Plain sewing } \\
\text { Ornamental } \\
\text { needlework } \\
\text { Embroidery } \\
\text { Tapestry } \\
\text { Drawing } \\
\text { Painting } \\
\text { Music } \\
\text { Politeness } \\
\text { French } \\
\text { Botany } \\
\text { Astronomy } \\
\text { Optics } \\
\text { Chemistry } \\
\text { Piano }\end{array}$ & 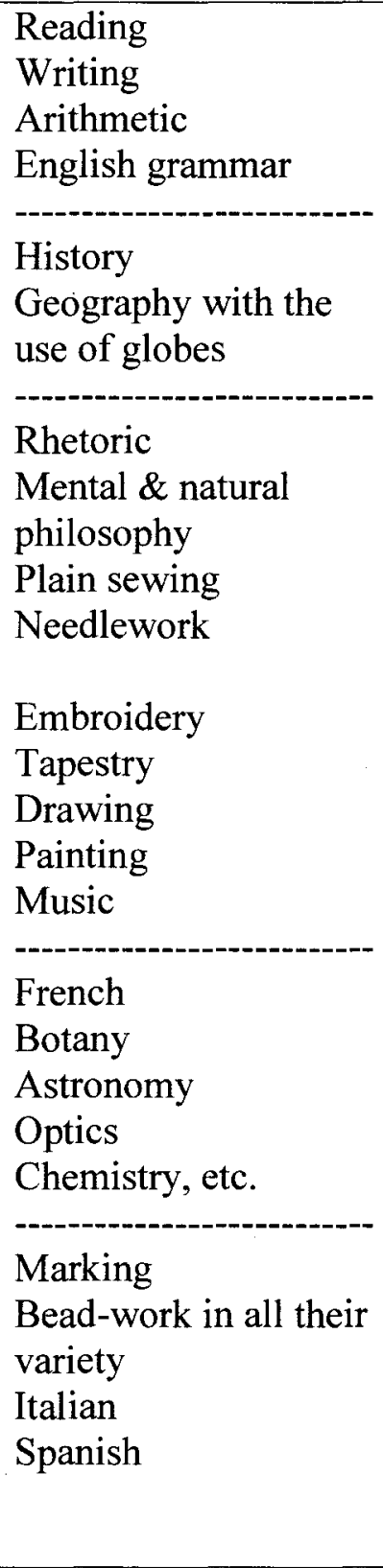 & $\begin{array}{l}\text { Reading } \\
\text { Writing } \\
\text { Arithmetic } \\
\text { English grammar } \\
\text { History } \\
\text { Geography with the } \\
\text { use of globes } \\
\text { Rhetoric } \\
\text { Mental \& natural } \\
\text { philosophy } \\
\text { Plain Sewing } \\
\text { Needlework } \\
\text { Embroidery } \\
\text { Tapestry } \\
\text { Drawing } \\
\text { Painting } \\
\text {-------------------------- } \\
\text { French } \\
\text { Botany } \\
\text { Astronomy } \\
\text { Optics } \\
\text { Chemistry, etc. } \\
\text {-------------- } \\
\text { Marking } \\
\text { Bead-work in all their } \\
\text { variety } \\
\text { Italian } \\
\text { Spanish } \\
\text { Latin } \\
\text { German }\end{array}$ \\
\hline
\end{tabular}

"While it was not listed with the curriculum, each Nazareth Academy Catalogue makes a point to note that "Lessons and Exercises in Polite Literature will also be given. The Institution was provided with a good library for the purpose." Entries have been rearranged to allow for easier comparison of curriculum.

Source: 1826: Clippings for Annals 1, Sisters of Charity of Nazareth Archival Center:1; 1833: 1833 United States Catholic Almanac 95-6, Sisters of Charity of Nazareth Archival Center.; 1858, 1870: Nazareth Academy Annual Catalogue, Sisters of Charity of Nazareth Archival Center. 


\title{
CURRICULUM VITA
}

\author{
Anna Powell \\ Vita \\ December 2012 \\ University of Louisville \\ Department of English \\ College of Arts and Science \\ Louisville, KY 40292 \\ Powell.anna.m@gmail.com
}

\section{Education}

M.A. 2012 University of Louisville. College of Arts and Sciences. Louisville, KY. Major: English - Literature

Thesis: "Lessons and Exercises in Polite Literature": The Pedagogy and Literature Curriculum of Mother Columba Carroll, a Sister of Charity of Nazareth

B.A. 2009 Southeast Missouri State University. College of Arts \& Sciences.

Cape Girardeau, MO

Major: English - Literature

Minor: History; Historic Preservation

\section{Professional Employment}

2010-present. Assistant Archivist. Sisters of Charity of Nazareth, Nazareth, KY.

2005-2009. Senior Student Assistant (PT). Special Collections and Archives, Southeast

Missouri State University, Cape Girardeau, MO.

\section{Professional Memberships \& Activities}

Society of American Archivists, Member

Kentucky Council on Archives, Member

- Administrative Board member and Newsletter Editor (2011-2014)

Kentucky State Historical Record Advisory Board (SHRAB) member

- Kentucky Archive Month Committee member

Midwest Archives Conference, Member

Archivists of Congregations of Women Religious, Member 


\section{Workshops}

Midwest Archives Conference

"Engaging Students and Teachers: Integrating Primary Sources in K - 16

Cirricula." 2012 MAC Fall Symposium, October 2012.

Kentucky's Cultural Heritage Initiative

"Disaster Planning for Cultural Collections" April 2010

Society of American Archivists

"Grant Proposal Writing" October 2012

"More Product, Less Process" May 2011

"Advanced Appraisal for Archivists" June 2010

Kentucky Council on Archives

"Managing Audio-Visual Materials in your Collection" May 2012

\section{Conference Presentations}

"Bringing Archives to the Classroom: Outreach to Junior High". Presented to the Kentucky Council on Archives Fall Meeting, Campbellsville, KY. October 5, 2012.

"Mind the Gaps: Leveraging Networks to Learn". Panel presented at the Midwest Archives Conference, Grand Rapids, MI. April 19, 2012. 